\title{
At the Intersection between Expropriation Law and Administrative Law: Two Critical Views on the Constitutional Court's Arun Judgment
}

\author{
EJ Marais* and PJH Maree ${ }^{\star *}$
}

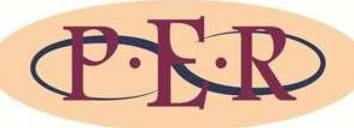

Author

Ernst Jacobus Marais

Petrus Jacobus Hermanus Maree

Affiliation

University of Johannesburg,

Stellenbosch University

South Africa

Email

ejmarais@uj.ac.za

mareepjh@gmail.com

Date published 26 August 2016

Editor Prof C Rautenbach

How to cite this article

Marais EJ and Maree PJH "At the Intersection between Expropriation Law and Administrative Law: Two Critical Views on the Constitutional Court's Arun Judgment" PER / PELJ 2016(19) - DOI

http://dx.doi.org/10.17159/1727-

3781/2016/v19i0a578

\section{Copyright}

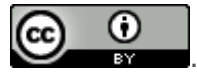

DOI

http://dx.doi.org/10.17159/17273781/2016/v19i0a578

\begin{abstract}
In Arun the Constitutional Court held that section 28 of the Land Use Planning Ordinance (LUPO) vests all land indicated as public roads on a development plan in the local authority upon approval of such a plan. This includes land that is in excess of the normal need of the development. The appellant must hence be compensated for the "expropriation" of such excess land if the provision is to comply with section 25(2) of the Constitution. This ruling is problematic for both expropriation law and administrative law.
\end{abstract}

In terms of section 25(2) four objections may be raised against the Arun decision. Firstly, it disregards the function of the public interest requirement for expropriation, as understood in view of the law-of-general-application requirement (which, in turn, is informed by the legality principle). The state cannot expropriate property for purposes that are ultra vires (or ulterior to) the authorising legislation. Yet the Arun court seems to allow just this by permitting the local authority to acquire land unrelated to the normal need of the development against payment of compensation instead of setting the attempted expropriation aside. The judgment, secondly, ignores the role of compensation under section 25(2). Merely paying compensation to an affected party cannot turn an invalid expropriation into a valid one, since compensation is merely the result of a valid expropriation and not a justification for it. Thirdly, it makes the distinction between deprivation and expropriation pivot on the effect of the property limitation, which is unable to properly distinguish between these two forms of limitation in all instances. Finally, Moseneke DCJ's ruling seems to afford an election to litigants who are affected by materially defective expropriations to choose whether to accept the expropriation and claim compensation or to have it reviewed and set aside under PAJA. This election, if it indeed exists, subverts the principles of expropriation law and may have negative repercussions for both expropriation law and administrative law, especially in view of the single-system-of-law principle.

From an administrative law perspective the authors identify four considerations that could assist courts in determining whether administrative law should be considered, if not applied, in a given case. The first is the internal coherency of the law in view of the subsidiarity principles. The subsidiarity principles provide guidelines for courts to decide cases where two fundamental rights might be applicable. A principled approach is necessary in this context to ensure that the law operates as a single system and displays the positive characteristics of such a system. The fact that Moseneke DCJ preferred to award compensation to Arun instead of reviewing the expropriation under PAJA runs contrary to these principles and seems to result in an outcome which endorses - instead of prevents - administrative injustice. Secondly, the Constitutional Court's refusal to follow PAJA by reason of its being onerous on the appellant contradicts earlier case law where the Court held that time-periods under the Act cannot be circumvented by reason of their being burdensome. The rationale behind these time-periods is integral to securing administrative justice, since time-periods are not merely formalistic technicalities. Thirdly, the authors argue that a green-light approach to internal remedies could have resulted in the broadening of the interpretative context and recognition of the legitimate role of the public administration in the state. Finally, deference as understood by Dyzenhaus also exemplifies why administrative law should not be ignored in cases which concern the exercise of public power. According to Dyzenhaus, deference requires courts to actively participate in the justification of administrative decisions by asking whether the administration's "reasoning did in fact and also could in principle justify the conclusion reached".

\section{Keywords}

Section 33; administrative law; lawfulness; legality principle; subsidiarity principles; expropriation; deprivation; section 25; property clause; constitutional property law; Arun case. 


\section{Introduction}

In Arun Property Development (Pty) Ltd $v$ Cape Town City (Arun) the Constitutional Court held that the vesting of excess land under section 28 of the Land Use Planning Ordinance 15 of 1985 (C) (LUPO; the Ordinance) results in an expropriation which must be compensated if the provision is to comply with section 25(2) of the Constitution of the Republic of South Africa, 1996 (the Constitution). This finding raises a number of questions for both expropriation law and administrative law. Our article therefore investigates this judgment from these two perspectives, more specifically section 25(2) and the Promotion of Administrative Justice Act 3 of 2000 (PAJA).

In terms of section 25(2) the decision, firstly, misconstrues the role of the public purpose and public interest requirements (hereafter referred to as the public interest requirement) in view of the law-of-general-application requirement, as informed by the legality principle. Secondly, it disregards the function of compensation for expropriation. It also places too much emphasis on the effect of the property limitation to properly distinguish between deprivation and expropriation. Finally, it seems to afford litigants affected by materially defective expropriations an election whether to challenge the attempted expropriation under PAJA - so as to set it aside or to simply accept the expropriation by claiming compensation. Such an election undermines the principles of expropriation law and has negative repercussions for both administrative law and the single-system-of-law principle $^{2}$ laid down in Pharmaceutical Manufacturers Association of South

* Ernst Jacobus Marais. BA LLB LLD (Stellenbosch University). Senior lecturer, Department of Private Law, Faculty of Law, University of Johannesburg. E-mail: ejmarais@uj.ac.za.

** Petrus Jacobus Hermanus Maree. BA LLB LLD (Stellenbosch University). Postdoctoral research fellow, Faculty of Law, Stellenbosch University. E-mail: mareepjh@gmail.com. This article is based on two papers that were delivered at respectively the Arun day seminar, co-hosted by the University of Johannesburg and the South African Research Chair in Property Law and held at the Constitutional Court auditorium on 17 July 2015, and the South African Property Law Teachers Colloquium, hosted by and held at the Law Faculty at the Potchefstroom Campus of North-West University on 5-6 November 2015. We would like to thank Prof Geo Quinot, Dr Elsabé van der Sijde and Mr Björn Hoops, who read and commented on earlier drafts of this article. Their comments greatly helped to refine our arguments. Thanks also go to Prof André van der Walt and Mr Björn Hoops for sharing draft copies of their publications with us. Any remaining errors are our own.

20152 SA 584 (CC).

This term belongs to Van der Walt Property and Constitution 16. 
Africa: In Re Ex Parte President of the Republic of South Africa ${ }^{3}$ (Pharmaceutical Manufacturers). Besides these objections it is questionable whether Arun should have been decided in terms of section 25(2) at all. We argue that the attempted expropriation under section 28 occurred by way of administrative action, which means it has to comply with the requirements for administrative justice under PAJA.

For an administrative law point of view we focus on four considerations that indicate the importance of PAJA to cases like Arun. First, we attend to the internal coherency of the law in view of the subsidiarity principles. In this context we address the phenomenon of litigants choosing the remedy which best suits their interests in situations where two fundamental rights apply to the same set of facts. Hereafter we concentrate on the nature and principles of administrative law, which underscore the relevance of this legal field in situations when the state exercises public powers or public functions. Our focus then shifts to a green-light reading of internal remedies and respect as deference. The former indicates that litigants ought to first exhaust any internal remedies available to them before attempting to review a decision under PAJA, while the latter expands the range of reasons that justify state action and which courts may take into consideration when ascertaining the validity of those actions.

To contextualise the discussion, section 2 provides a brief overview of the factual background and reasoning of the Constitutional Court in Arun. Section 3 then sets out the objections to the judgment from a section 25(2) perspective. The next section (section 4), in turn, identifies the difficulties under administrative law and indicates the relevance of PAJA to cases such as the present. Finally, section 5 presents a summary of our arguments and the conclusion.

\section{Factual background and the Constitutional Court's judgment ${ }^{4}$}

Arun Property Development (Arun; the appellant) wished to undertake residential development on land it owned in the Western Cape. It therefore submitted an application to the City of Cape Town (the local authority; the city) to obtain the necessary permission to subdivide its land. The city informed Arun that it would approve the subdivision application only if

20002 SA 674 (CC).

For a discussion of the Arun case from a planning law perspective, see Van Wyk 2016 PELJ. 
Arun's development plan provided for overly broad roads that would run over its land, since this would aid in the construction of future higher-order roads planned for the region as a whole. ${ }^{5}$ These roads would then vest in the city, since section 28 of LUPO $^{6}$ provides that ownership of all land indicated as public streets on a development plan vests in the local authority upon approval of the plan, if the provision of the said public streets is necessary for the normal need of the development. The appellant made provision for these overly broad roads on its development plan and the local authority subsequently granted it permission (under section 25 of LUPO) to subdivide the land.

The appellant thereupon instituted legal proceedings on the basis that it is entitled to compensation under section 28 for any land that vested in the city and which is unrelated to the normal need of the development (hereafter referred to as the excess land). The Constitutional Court, in a unanimous judgment, interpreted section 28 as vesting all land, including excess land, indicated as public roads on the development plan in the local authority upon confirmation of the subdivision. ${ }^{7}$ Against this backdrop the Court ruled that the local authority must compensate Arun for the expropriation of excess land if the provision is to comply with section 25(2) of the Constitution. ${ }^{8}$

Moseneke DCJ relied mainly on three considerations to categorise the vesting as expropriation. He assumed, without deciding, that expropriation occurs through state coercion and without the consent of the affected party - both of which were satisfied on the facts. ${ }^{9}$ It was also found that

5 Both Arun and the local authority assumed, without the local authority's conceding, that certain portions of land indicated as roads on the development plan were in excess of the normal need of the development: see Arun (CC) para 15.

$6 \quad$ "Ownership, on subdivision, of public streets and public places. - The ownership of all public streets and public places over or on land indicated as such at the granting of an application for subdivision under section 25 shall, after the confirmation of such subdivision or part thereof, vest in the local authority in whose area of jurisdiction that land is situated, without compensation by the local authority concerned if the provision of the said public streets and public places is based on the normal need therefor arising from the said subdivision or is in accordance with a policy determined by the Administrator from time to time, regard being had to such need."

7 Marais 2016 SALJ argues that this extensive interpretation of $S 28$ of LUPO is unjustified when regard is had to relevant contextual factors, which the Court seems to have ignored. For a contrary view, see Van Wyk 2016 PELJ 17.

8 The vesting of land indicated as public roads which is required for the normal need of the development need not be compensated: see Arun (CC) paras 35, 40.

9 Moseneke DCJ in Arun (CC) para 58 relied on Van der Walt Constitutional Property Law 344 to make this finding, where the author states that "expropriation is brought 
the vesting of excess land in the local authority without compensation is unrelated to the purpose of section 28. ${ }^{10}$ For this reason Arun had to receive compensation under section 26(1) of the Expropriation Act 63 of 1975 (the Expropriation Act) for the expropriation of the excess land if the provision was to comply with section $25(2)$ of the Constitution.

The city argued that Arun cannot claim compensation for an expropriation before it has exhausted its internal remedies under LUPO or, alternatively, that it should have had the decision that resulted in the expropriation reviewed under PAJA so as to have it set aside. Moseneke DCJ rejected these arguments for two reasons. He reasoned that it would be onerous to expect the appellant to follow the administrative law route. Secondly, he did not see why "Arun should be obliged to follow a process to set aside an administrative decision, whose lawfulness it has accepted and implemented". ${ }^{11}$

The next section investigates the requirements for a valid expropriation and argues that the purpose behind the expropriation of the excess land is one which is not sanctioned by section 28 of the Ordinance. The section examines the status of expropriations that do not comply with one or more of the section 25(2) requirements and then identifies the method of expropriation at hand. In view of this analysis it appears that Moseneke DCJ treated the expropriation in Arun as an invalid (and thus defective) expropriation which may nevertheless be upheld at the insistence of the affected party, as long as it serves some conceivable public purpose or public interest, even one not sanctioned by the authorising statute. Against this backdrop section 4 focuses on the administrative law perspective of the case and argues that PAJA should have played a more prominent role in the Court's decision.

\section{The expropriation question}

\subsection{Section 25(2) requirements}

Before examining the requirements for expropriation under section 25(2), it is necessary at the outset to attend to three characteristics common to most expropriations in order to clarify their role in our expropriation law,

about unilaterally by state action, without the cooperation (and often against the will) of the affected owner."

10 Arun (CC) para 40.

11 Arun (CC) para 70. 
especially since two of them featured in Moseneke DCJ's judgment. ${ }^{12}$ The first is that expropriation is generally a process whereby a property holder is deprived of property, which then vests in the state. ${ }^{13}$ Although section 25(2) does not explicitly set state acquisition as a requirement for expropriation, the Constitutional Court decided in Agri South Africa $v$ Minister for Minerals and Energy ${ }^{14}$ (Agri SA) that the state must acquire property for there to be expropriation. ${ }^{15}$ Absent such acquisition, the property limitation ${ }^{16}$ can at most amount to a deprivation of property. The second and third features are that expropriation occurs through state

12 Arun (CC) para 58. These two characteristics are discussed in the next paragraph below.

13 Harksen v Lane 19981 SA 300 (CC) paras 31-32; Tongaat Group Ltd v Minister of Agriculture 19772 SA 961 (A) 972; Pretoria City Council v Modimola 19663 SA 250 (A) 258; Beckenstrater v Sand River Irrigation Board 19644 SA 510 (T) 515. Also see Gildenhuys and Grobler "Expropriation" para 1; Badenhorst, Pienaar and Mostert Silberberg and Schoeman 102, 541, 563; Gildenhuys Onteieningsreg 61; Van der Merwe Sakereg 291.

1420134 SA 1 (CC).

15 Agri SA paras 58-59, citing Harksen $v$ Lane 19981 SA 300 (CC) paras 31-32 and Reflect-All 1025 CC v MEC for Public Transport, Roads and Works, Gauteng Provincial Government 20096 SA 391 (CC) para 63. What is acquired by the state must bear "substantial similarity" or "sufficient congruence" with the property lost by the affected property holder: see Agri SA para 58. The debate whether state acquisition is now an indispensable requirement for expropriation will be settled by the Expropriation Bill B4D-2015 once it is signed into law, as it defines "expropriation" as "the compulsory acquisition of property by an expropriating authority or an organ of state upon request to an expropriating authority". For problems with viewing state acquisition as a "key" requirement for expropriation, see Van der Walt Constitutional Property Law 194-200; Marais 2015 PELJ (Part I); Marais 2015 PELJ (Part II). Compare the minority opinions of Cameron $\mathrm{J}$ and Froneman $\mathrm{J}$ in Agri $S A$, who are hesitant to recognise state acquisition as the defining characteristic of expropriation.

16 We deliberately do not use the terms "interference" and "infringement" to refer to the regulation of property by way of deprivation or, more broadly, expropriation. This is because these terms create the impression that property is an absolute, unrestricted right and that its regulation is therefore exceptional and temporary. Instead, by relying on Van der Sijde Reconsidering the Relationship Between Property and Regulation 147-152, we use the term "limitation" to describe the impact of deprivation and expropriation on property, since these forms of regulation should be seen as inherent to the system of which property forms part. The view that property is a pre-constitutional, unregulated right that can be limited only under exceptional circumstances is incompatible with the single-system-of-law principle laid down in Pharmaceutical Manufacturers: see Van der Sijde Reconsidering the Relationship between Property and Regulation 150-151. A theoretical discussion of how property should be construed is beyond the scope of this article. For a discussion in this regard, see Van der Sijde Reconsidering the Relationship between Property and Regulation ch 2. 
coercion and (normally) without the cooperation of the affected property holder. ${ }^{17}$

It is uncontroversial that the state acquires property in the majority of expropriation cases and for this reason the acquisition requirement is helpful for distinguishing between deprivation and expropriation. ${ }^{18}$ However, the mere fact that acquisition is now a key requirement of expropriation does not mean that every acquisition of property by the state is also an expropriation. ${ }^{19}$ Such an effect-centred analysis is overly simplistic, since the distinction between deprivation and expropriation does not hinge on the mere effect of the limitation. ${ }^{20}$ The same criticism may be raised against the two other features mentioned in the previous paragraph. ${ }^{21}$ This is because certain deprivations, such as taxation and criminal forfeiture, also exhibit these characteristics without amounting to expropriation. ${ }^{22}$ It follows that none of the three factors referred to are able to adequately categorise a property limitation as either deprivation or expropriation. To determine whether section 28 of LUPO truly results in a valid expropriation, it is necessary to analyse this provision in the context of the requirements for expropriation under section 25(2) of the Constitution.

Section 25(2) stipulates that property may only be expropriated in terms of law of general application for a public purpose or in the public interest against payment of compensation. ${ }^{23}$ The rest of this section addresses each of these three requirements in turn. The "law" in this provision refers to statute law, since South African law does not recognise common-law expropriation. ${ }^{24}$ Expropriation is a public power that accrues only to the

17 Arun (CC) para 58, approving Van der Walt Constitutional Property Law 344. Also see Pretoria City Council v Modimola 19663 SA 250 (A) 258. See further Gildenhuys and Grobler "Expropriation" para 1.

18 Van der Walt Constitutional Property Law 197, 345; Marais 2015 PELJ (Part II) 3035-3037.

19 Van der Walt Constitutional Property Law 196-199, 315-319; Marais 2015 PELJ (Part II) 3035-3039. Also see Van der Walt 2014 ASSL; Slade 2016 PELJ 17-18.

20 Van der Walt Constitutional Property Law 196-199, 315-319; Marais 2015 PELJ (Part I) 3014-3022; Marais 2015 PELJ (Part II) 3035-3039.

21 Arun (CC) paras 55, 58, approving Van der Walt Constitutional Property Law 344. Also see Pretoria City Council v Modimola 19663 SA 250 (A) 258. See further Gildenhuys and Grobler "Expropriation" para 1.

22 Van der Walt Constitutional Property Law 196-199, 315-319; Marais 2015 PELJ (Part II) 3035-3039.

23 Compare ss 2(1) and 2(3) of the Expropriation Bill B4D-2015.

24 President of the Republic of South Africa v Modderklip Boerdery (Pty) Ltd 20055 SA 3 (CC) para 63; Harvey v Umhlatuze Municipality 20111 SA 601 (KZP) para 81; Groengras Eiendomme (Pyt) Ltd v Elandsfontein Unlawful Occupants 20021 SA 
state. ${ }^{25}$ As a public power expropriation is subject to the principle of legality, which entails that the state may exercise powers and perform functions only in as far as they are conferred on it by law. ${ }^{26}$ The state may thus expropriate property only in terms of legislation that specifically authorises it to use this power. ${ }^{27}$ The empowering legislation must also set out the circumstances, procedures and conditions upon which expropriation may take place. ${ }^{28}$

The legality principle requires the empowering statute to clearly delineate the purpose (or purposes) for which property may be expropriated, since the state may expropriate property only for purposes permitted by the authorising legislation. ${ }^{29}$ In this regard the legality principle informs the

125 (T) para 23; Joyce \& McGregor Ltd v Cape Provincial Administration 1946 AD 658 671; Pretoria City Council v Modimola 19663 SA 250 (A) 258. Also see Gildenhuys Onteieningsreg 9-10; Van der Walt Constitutional Property Law 453; Van der Walt and Marais 2012 LitNet Akademies 304-305; Roux "Property" 33.

25 Harvey $v$ Umhlatuze Municipality 20111 SA 601 (KZP) para 81; Groengras Eiendomme (Pyt) Ltd v Elandsfontein Unlawful Occupants 20021 SA 125 (T) para 23; Pretoria City Council v Modimola 19663 SA 250 (A) 258; Joyce \& McGregor Ltd $v$ Cape Provincial Administration 1946 AD 658 671. Also see Van der Walt Constitutional Property Law 344, 452-456; Badenhorst, Pienaar and Mostert Silberberg and Schoeman 566; Gildenhuys Onteieningsreg 9-10, 49, 93.

26 Fedsure Life Assurance Ltd $v$ Greater Johannesburg Transitional Metropolitan Council 19991 SA 374 (CC) paras 56 and 58; Pharmaceutical Manufacturers para 20; Minister of Health v New Clicks South Africa (Pty) Ltd 20062 SA 311 (CC) para 144. Also see Gildenhuys and Grobler "Expropriation" para 13. Compare Van der Sijde Reconsidering the Relationship between Property and Regulation 212-213.

27 Joyce \& McGregor Ltd v Cape Provincial Administration 1946 AD 658 671; Pretoria City Council v Modimola 19663 SA 250 (A) 258; Harvey v Umhlatuze Municipality 20111 SA 601 (KZP) para 81; Groengras Eiendomme (Pty) Ltd v Elandsfontein Unlawful Occupants 20021 SA 125 (T) para 23; s 2(3) of the Expropriation Bill B4D2015. Also see Van der Walt Constitutional Property Law 453-454; Gildenhuys and Grobler "Expropriation" para 12; Gildenhuys Onteieningsreg 10, 49-59.

28 Gildenhuys Onteieningsreg 9-10; s 2(3) of the Expropriation Bill B4D-2015. Also see Groengras Eiendomme (Pty) Ltd v Elandsfontein Unlawful Occupants 20021 SA 125 (T) para 23; City of Cape Town v Arun Property Developments (Pty) Ltd 2014 JDR 0786 (SCA) (Arun (SCA)) para 23. However, in Arun (CC) para 38 Moseneke DCJ seems to reject the finding of Mathopo AJA in Arun (SCA) that the statute must provide for a procedure whereby expropriation may take place. Nonetheless, $s$ 2(3) of the Expropriation Bill B4D-2015 will override this obiter dictum once it is signed into law.

29 Harvey $v$ Umhlatuze Municipality 20111 SA 601 (KZP) para 81; Groengras Eiendomme (Pty) Ltd v Elandsfontein Unlawful Occupants 20021 SA 125 (T) para 23; L F Boshoff Investments (Pty) Ltd v Cape Town Municipality; Cape Town Municipality v L F Boshoff Investments (Pty) Ltd 19692 SA 256 (C) 268; White River Village Council v H L Hall \& Sons Ltd 19582 SA 524 (A) 530-531; Broadway Mansions (Pty) Ltd v Pretoria City Council 19551 SA 517 (A) 522; Estate Geekie v Union Government 19482 SA 494 (N) 502-503; Van Eck and Van Rensburg v Etna Stores 19472 SA 984 (A) 996-998. Also see Gildenhuys and Grobler "Expropriation" 
law-of-general-application requirement in section 25(2), ${ }^{30}$ which requires the applicable law to be sufficiently precise and specific. ${ }^{31}$ The power to expropriate for purposes ulterior to the empowering statute therefore does not exist - such (attempted) expropriations are ultra vires the authorising legislation and must be set aside by a court. ${ }^{32}$ Consequently, the state may not expropriate property for purposes other than those permitted by the empowering statute, irrespective of how laudable these ulterior purposes may be. ${ }^{33}$ Against this background section 28 of LUPO must be distinguished from statutes that permit expropriation for a wide range of purposes. Section 2(1) of the Expropriation Act is one such example, since it allows the Minister to expropriate property for any purpose that is a public purpose or in the public interest (if one reads section 2(1) with section 25(2) of the Constitution). ${ }^{34}$ The purpose for which land indicated as public streets on a development plan may vest in the local authority pursuant to section 28 of LUPO, on the other hand, is limited to the provision of public roads required for the normal need of the planned development. ${ }^{35}$

Furthermore, a valid expropriation requires the payment of just and equitable compensation, as required by section $25(2)(b)$ and $25(3)$ of the Constitution. In the absence of a compensation provision in the authorising

para 13; Van der Walt Constitutional Property Law 452-456; Gildenhuys Onteieningsreg 10, 49-59.

30 See similarly Van der Sijde Reconsidering the Relationship between Property and Regulation 217-219, 244.

31 Woolman and Botha "Limitations" 34-48-34-50. See similarly Hoops 2016 SALJ ss IV and $\mathrm{V}(\mathrm{b})$, who argues that the preciseness requirement of the law-of-generalapplication requirement is comparable to the principle of specificity (Bestimmtheitsgebot) in German expropriation law. In the German context this principle requires that legislation which authorises expropriation "should sufficiently specify the purposes and the projects for which property can be expropriated" (Hoops 2016 SALJ S IV).

32 Administrateur, Transvaal v Quid Pro Quo Eiendomsmaatskappy (Edms) Bpk 19774 SA 829 (A) 837-842, which was confirmed by the Constitutional Court in Minister of Education v Harris 20014 SA 1297 (CC) paras 17-19. See similarly L F Boshoff Investments (Pty) Ltd v Cape Town Municipality; Cape Town Municipality v L F Boshoff Investments (Pty) Ltd 19692 SA 256 (C) 268; White River Village Council v H L Hall \& Sons Ltd 19582 SA 524 (A) 530-531; Broadway Mansions (Pty) Ltd v Pretoria City Council 19551 SA 517 (A) 522; Estate Geekie v Union Government 19482 SA 494 (N) 502-503. Also see Gildenhuys and Grobler "Expropriation" para 13; Gildenhuys Onteieningsreg 49, 59 fn 80. Compare the position in German expropriation law: see Hoops 2016 SALJ S IV and the sources he cites.

33 Van Eck and Van Rensburg v Etna Stores 19472 SA 984 (A), citing Fernwood Estates Ltd v Cape Town Municipal Council 1933 CPD 399403.

34 Hoops 2016 SALJ ss I and III(b). Compare s 3(1) of the Expropriation Bill B4D-2015. 
legislation there is a rebuttable presumption that the statute does not authorise expropriation at all. ${ }^{36}$ In this context it must be emphasised that expropriation is justified only by the valid purpose it serves and not by the mere payment of compensation. ${ }^{37}$ Compensation for expropriation must therefore be carefully distinguished from damages for delict, since expropriatory compensation is the result of a lawful (as opposed to an unlawful) property limitation under section 25(2). ${ }^{38}$

Moseneke DCJ did not focus on the state acquisition requirement to establish whether section 28 of LUPO authorises expropriation, although he did refer to it in passing. ${ }^{39}$ This may be attributed to the fact that this requirement is (according to Moseneke DCJ's interpretation of section 28) satisfied on the facts - the local authority acquires property in the form of excess land from the developer upon approval of the subdivision application under section 25 of LUPO. Yet he did rely on the two other characteristics mentioned above to decide the expropriation question. The fact that these features were satisfied on the facts led him to rule that section 28 results in expropriation of excess land. ${ }^{40}$ However, as discussed earlier, these two characteristics are unable to accurately categorise a property limitation as either deprivation or expropriation. Interestingly, Moseneke DCJ referred to the purpose of section 28 and held that the "compulsory taking away of excess land without compensation is not properly related to the purpose of developing a

36 Gildenhuys Onteieningsreg 18, citing Belinco (Pty) Ltd v Bellville Municipality 19704 SA 589 (A). Also see Marais 2016 SALJ S III(b) and compare Administrator, Cape v Associated Buildings Ltd 19572 SA 317 (A); Administrator, Cape Province v Ruyteplaats Estates (Pty), Ltd 19521 SA 541 (A); Steyn Uitleg van Wette 105-107. Although ss $25(2)$ and $25(3)$ of the Constitution does not stipulate that the authorising statute must specifically provide for the nature and amount of compensation (compare the linking clause or Junktim Klausel in Article 14.3.2 GG: see Van der Walt Constitutional Property Law 366-367 and fn 114; Van der Walt Constitutional Property Clauses 149-151, citing BVerfGE 58, 300 (1981); Kleyn 1996 SAPL 435), it could be argued that this presumption in South African law performs a function comparable to that of the linking clause in German law.

37 Harvey v Umhlatuze Municipality 20111 SA 601 (KZP) para 82; Minister of Minerals and Energy $v$ Agri South Africa 20125 SA 1 (SCA) para 18, which was not overturned by the Constitutional Court on appeal. Also see Van der Walt Constitutional Property Law 496; Slade 2013 TSAR 199 and compare Gildenhuys Onteieningsreg 65.

38 Gildenhuys Onteieningsreg 3; Kleyn 1996 SAPL 442.

39 Arun (CC) para 58, quoting with approval from City of Cape Town v Helderberg Park Development (Pty) Ltd 20086 SA 12 (SCA) para 40 which, in turn, relies on Beckenstrater v Sand River Irrigation Board 19644 SA 510 (T) 515. 
township with adequate public roads and spaces". ${ }^{41} \mathrm{He}$ also ruled, albeit by way of obiter dicta, that section 28 does not authorise a deprivation of property beyond the normal need of the development, as such deprivation would take place outside legislative authority. ${ }^{42}$ Against this background he concluded that the appellant must be compensated if section 28 is to comply with section 25(2) of the Constitution.

Moseneke DCJ's finding that section 28 authorises an expropriation which must be compensated is characterised by three flaws if regard is had to the requirements in section 25(2). The first concerns the purpose of the expropriation in view of the law-of-general-application requirement and the principle of legality. The fact that the vesting of excess land under section 28 is - according to the Court - not properly related to the purpose the provision seeks to achieve means that the power to expropriate land for purposes other than the normal need of the development does not exist. Stated differently, section 28 does not in any way authorise expropriation of excess land. ${ }^{43}$ The fact that the vesting of excess land in the local authority could serve a purpose which may be valid in another context (ie to aid the construction of future higher-order roads) does not mean that section 28 authorises the expropriation of such land. ${ }^{44}$ To answer the authorisation question it must be established whether or not section 28 permits the expropriation of excess land to realise this latter purpose.

The purpose of section 28 is to develop townships with adequate public roads and spaces. ${ }^{45}$ This purpose does not envisage the expropriation of excess land and section 28, when understood in view of the legality principle, therefore does not grant the state the power to expropriate excess land in this context. ${ }^{46}$ The purpose which the vesting of excess land seeks to achieve is simply ultra vires the empowering statute and any expropriation aimed at realising this purpose is therefore invalid. The fact that the provision does not set out the circumstances, procedures and conditions upon which expropriation may take place, while also not

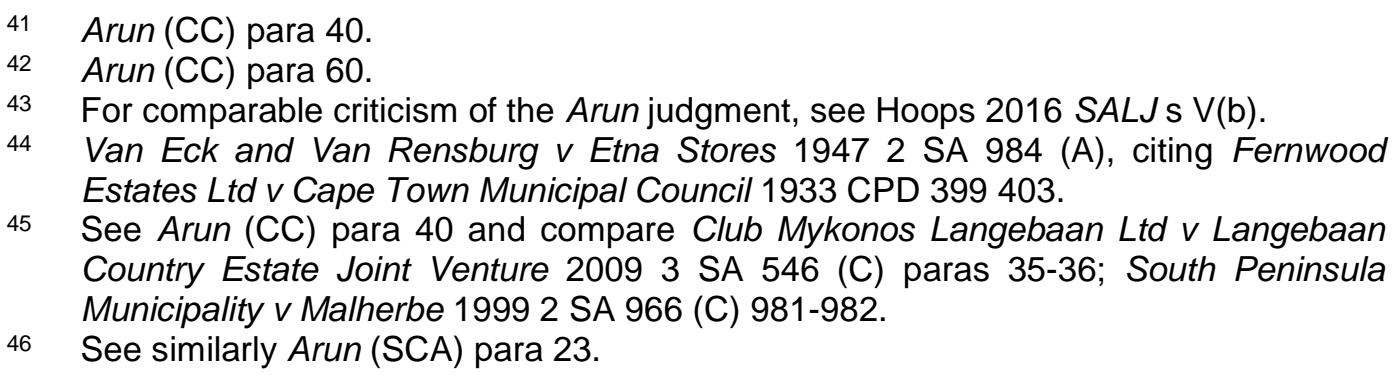

45 See Arun (CC) para 40 and compare Club Mykonos Langebaan Ltd $v$ Langebaan Country Estate Joint Venture 20093 SA 546 (C) paras 35-36; South Peninsula Municipality v Malherbe 19992 SA 966 (C) 981-982. 
providing compensation, supports this argument. ${ }^{47}$ In addition, case law and academic scholarship on section 28 reveal that it vests land indicated as public streets in the local authority only in so far as it is required for the normal need of the development. ${ }^{48}$ What the normal need of the development entails is a factual question that will differ from case to case. ${ }^{49}$ The vesting of land required for the normal need of the development merely amounts to a non-arbitrary deprivation of property that does not require compensation. ${ }^{50}$ Furthermore, other decisions on section 28 of LUPO (and also its predecessor) ${ }^{51}$ reveal that any attempt by a local authority to acquire land unrelated to the normal need of the development is ultra vires the provision and therefore invalid. ${ }^{52}$

The above line of reasoning is strengthened by the Court's ruling that the provision does not authorise any deprivation of property beyond the normal need of the development. It is worth mentioning that, in view of the subset distinction between deprivation and expropriation laid down in First National Bank of SA Ltd t/a Wesbank $v$ Commissioner, South African Revenue Service; First National Bank of SA Ltd t/a Wesbank $v$ Minister of Finance $^{53}(F N B)$, it is difficult to see how a provision can result in expropriation - the most extreme property limitation - if it does not even authorise deprivation, which is a lesser form of limitation. ${ }^{54}$ Moseneke

47 Section 28 merely stipulates that compensation is not payable - it does not, by necessary implication, reveal when compensation is payable: see Marais 2016 SALJ s III(c)(I). For a contrary view, see Arun (CC) para 33 (citing Heher JA in City of Cape Town v Helderberg Park Development (Pty) Ltd 20086 SA 12 (SCA) para 41) and Van Wyk 2016 PELJ 16-17.

48 Van der Walt Constitutional Property Law 270-272, 289-291; Van der Walt 2008 ASSL 245-247; Van Wyk Planning Law 369-372; Slade 2016 PELJ 4, 13-14; Marais 2016 SALJ S III(C)(ii). For a contrary view, see Arun (CC) para 32 and Van Wyk 2016 PELJ 16-17.

49 Compare Dolan v City of Tigard 512 US 374 (1994).

50 See the sources mentioned in fn 48 above. Moseneke DCJ seems to endorse this view: see Arun (CC) paras 35 and 40. Also see Van Wyk 2016 PELJ 19-20.

51 Township Ordinance 33 of 1934 (C).

52 South Peninsula Municipality v Malherbe 19992 SA 966 (C); Club Mykonos Langebaan Ltd $v$ Langebaan Country Estate Joint Venture 20093 SA 546 (C); Belinco (Pty) Ltd v Bellville Municipality 19704 SA 589 (A); Administrator, Cape Province v Ruyteplaats Estates (Pty), Ltd 19521 SA 541 (A); Administrator, Cape v Associated Buildings Ltd 19572 SA 317 (A). Also see Marais 2016 SALJ s III(b).

5320024 SA 768 (CC).

54 Marais 2016 SALJ S III(c)(ii). See similarly Slade 2016 PELJ 14-15 and fn 49. According to Marais (at $\mathrm{S} \mathrm{III(C)(ii))} \mathrm{this} \mathrm{finding} \mathrm{raises} \mathrm{the} \mathrm{question} \mathrm{whether} \mathrm{the} \mathrm{Court}$ still adheres to the FNB subset distinction or has perhaps returned to the conceptual distinction (see Van der Walt and Botha 1998 SAPL) laid down in Harksen to distinguish between deprivation and expropriation. This is exacerbated by the fact that Moseneke DCJ did not refer to either of these cases in his judgment, despite that fact that he agreed with Mogoeng CJ's majority ruling in Agri SA, where the FNB 
DCJ's finding that section 28 does not authorise a deprivation of excess land therefore undermines his conclusion that this provision results in an expropriation of such land under section 25(2).

The second flaw pertains to the function of compensation under section 25(2). As mentioned above, expropriation is justified only by the public purpose or public interest it serves. Compensation is therefore merely a consequence of a valid expropriation and not a justification for it. The reference in section 28 to when compensation is not payable is unhelpful for determining whether the provision authorises expropriation, since the mere payment of compensation cannot bring a purpose, which is otherwise beyond the scope of the empowering provision, within its ambit. The purpose behind an expropriation is either sanctioned by the legislation or it is not. Consequently, the power to expropriate in this context cannot be brought into existence simply by awarding compensation to the affected party ex post facto. Moseneke DCJ's award of compensation to Arun for an expropriation which aims to realise a purpose ulterior to section 28 of LUPO is therefore misplaced.

Finally, the Court overemphasised the effect of the property limitation to decide the expropriation question by focusing on two of the three characteristics of expropriation discussed above. The pitfalls associated with - and possible solutions to - such an effect-centred approach to decide the expropriation question have been dealt with in more detail elsewhere and will hence not be repeated here. ${ }^{55}$ Suffice it to say, as stated earlier, that the distinction between deprivation and expropriation does not pivot on the effect of the limitation. ${ }^{56}$ It seems that the danger of Mogoeng CJ's effect-centred approach adopted in Agri SA for deciding the expropriation question - which simply focuses on the effect of the property limitation - has indeed been realised in Arun. ${ }^{57}$ For this reason, and the two others discussed above, Moseneke DCJ's finding that section 28 of LUPO authorises the expropriation of excess land which requires compensation is unconvincing. ${ }^{58}$

subset distinction was approved. Nevertheless, this interesting matter is beyond the scope of our article.

55 See Marais 2015 PELJ (Part I); Marais 2015 PELJ (Part II).

56 Van der Walt Constitutional Property Law 347-349.

57 This danger is pointed out by Marais 2015 PELJ (Part I); Marais 2015 PELJ (Part II).

58 See similarly Marais 2016 SALJ. Also see Van der Sijde Reconsidering the Relationship between Property and Regulation 7-8. 
Nevertheless, the Court reasoned that the absence of a nexus between the vesting of excess land and the purpose behind it, namely to aid the construction of future higher-order roads, would result in section 28 being unconstitutional if Arun were not compensated for the loss of this land. 59 Moseneke DCJ thus preferred to save section 28 by giving it a meaning that is - seemingly - "at peace" with section 25(2). Such a meaning, in his view, requires interpreting the provision as providing compensation for the expropriation of excess land. ${ }^{60}$ However, first principles reveal that the vesting of excess land under section 28 in actual fact results in an invalid expropriation not properly related to a purpose authorised by this provision. Still, the fact that Moseneke DCJ interpreted section 28 as authorising expropriation makes it necessary to ascertain the method of expropriation under this provision.

\subsection{Method of expropriation}

South African law appears to recognise three methods of expropriation, namely administrative expropriation, judicial expropriation and statutory expropriation. ${ }^{61}$ Administrative expropriation entails that expropriation is brought about by administrative action where an administrator, acting in terms of an empowering statute, exercises a discretion when deciding to expropriate property for a purpose permitted by the empowering statute. ${ }^{62}$ Judicial expropriation occurs where the expropriation is affected by a court order. ${ }^{63}$ Statutory expropriation, in turn, is brought about directly by the

59 Arun (CC) para 41. Compare the finding that compensation is not required for the vesting of land in the local authority which is required for the normal need of the development: see Arun (CC) paras 35, 40.

60 Marais 2016 SALJ addresses the problems of such a construal from an interpretation-of-statutes perspective.

61 Gildenhuys and Grobler "Expropriation" para 3; Van der Walt Constitutional Property Law 456-458. Gildenhuys Onteieningsreg 14-15, 77-78 gives only mentions administrative and judicial expropriation as the two methods of expropriation in South African law. Compare s 2(3) of the Expropriation Bill B4D-2015, which seems to exclude statutory expropriation (and perhaps also constructive expropriation) as a method for expropriation in South African law.

62 Gildenhuys Onteieningsreg 14-15; Van der Walt Constitutional Property Law 456; Gildenhuys and Grobler "Expropriation" para 3. The majority of expropriations occur by way of administrative action: see Gildenhuys Onteieningsreg 14-15; Gildenhuys and Grobler "Expropriation" para 3.

63 Gildenhuys and Grobler "Expropriation" para 3; Gildenhuys Onteieningsreg 14. Gildenhuys and Grobler "Expropriation" para 3 and Roux "Property" 33 mention expropriation in favour of a labour tenant under the Land Reform (Labour Tenants) Act 3 of 1996 as an example of judicial expropriation. 
enactment of legislation and in the absence of any administrative action. ${ }^{64}$ It is unclear whether South African law actually recognises this latter method of expropriation, although the Supreme Court of Appeal seems to assume that it does. ${ }^{65}$

Identifying the method of expropriation under section 28 , however, is no easy task. Moseneke DCJ's findings as to the actual cause of the vesting of excess land in the local authority - namely whether it occurred by operation of law or because of the approval of the development plan appear to be contradictory. He initially holds that the vesting occurs by operation of law after approval of the subdivision application, which creates the impression that the expropriation took place by way of administrative action. ${ }^{66}$ Yet he ruled elsewhere that the "loss of ownership is compelled by law, and not by the decision of the local authority", ${ }^{67}$ which seems to point to statutory expropriation. ${ }^{68}$ Closer examination, however, reveals that the latter finding is inaccurate. The phrase "ex lege" or "by operation of law" means that certain legal consequences follow upon satisfaction of objective requirements set by law and in the absence of any decision (in the form of administrative action). An example of such a consequence is the extinguishment of old order rights under the Mineral and Petroleum Resources Development Act 28 of 2002 (MPRDA). According to the transitional provisions ${ }^{69}$ of the MPRDA, old order rights ${ }^{70}$ remained in force for certain periods of time after the commencement of the Act. If the holders of these rights failed (or were unable) to convert them into new order rights, they ceased to exist at the expiration of the

64 Van der Walt Constitutional Property Law 457; Gildenhuys and Grobler "Expropriation" para 3; Kleyn 1996 SAPL 435-436.

65 Minister of Minerals and Energy v Agri South Africa 20125 SA 1 (SCA) para 15. This finding was not overturned by the Constitutional Court on appeal. See further the discussion in fn 61 above.

66 Arun (CC) para 40. Compare para 61, where the Court - with reference to the wording of $\mathrm{s} 28$ - held that the vesting is a direct sequel of the confirmation of the subdivision. See similarly Van der Walt 2014 ASSL with reference to para 70 of the judgment.

67 Arun (CC) para 59 (emphasis added). Compare para 65. Yet, in the very next sentence after the quoted phrase Moseneke DCJ states that the vesting "occurs instantly upon confirmation of the subdivision", which indicates that the vesting depends on the approval of the subdivision application and does not occur ex lege.

68 See similarly Van der Walt 2014 ASSL; Van der Sijde Reconsidering the Relationship between Property and Regulation 5-6, 202-203.

69 Items 6-8 of Schedule II to the MPRDA.

70 These included old order prospecting rights, old order mining rights and unused old order rights. 
relevant period. ${ }^{71}$ The extinction of these old order rights, which amounted to constitutional property, ${ }^{72}$ occurred by operation of law and did not depend on the exercise of any discretion. The fact that a developer's loss of excess land, which is the result of the vesting under section 28 of LUPO, cannot occur without the approval of the subdivision application by the local authority under section 25 - which entails the exercise of a discretion - therefore undermines the finding that such vesting could have occurred ex lege. ${ }^{73}$ The approval of the development plan is simply a conditio sine qua non for the vesting of any land in the local authority.

Indeed, section 28 stipulates that "ownership of all public streets ... over or on land indicated as such at the granting of an application for subdivision under section 25 shall, after the confirmation of such subdivision or part thereof, vest in the local authority". ${ }^{74}$ It is therefore impossible to divorce the consequence (ie the vesting of excess land) from its cause (ie the approval of a subdivision application pursuant to section 25). It follows that no land - whether required for the normal need of the development or in excess of such need - can vest in the local authority without the approval of a subdivision application. Consequently, the vesting was caused by a decision to grant approval of an application to subdivide, which is administrative action and must hence comply with the requirements for just administrative action under section 33 of the Constitution and PAJA. ${ }^{75}$ An administrator acting in terms of section 25 will thus have to be mindful of the interrelatedness of this provision with the "expropriatory element" in section 28 when approving development plans. It follows that the expropriation of excess land under section 28 most probably took place by way of administrative expropriation. ${ }^{76}$

71 The periods for which old order prospecting rights, old order mining rights and unused old order rights continued to be in force after the commencement of the MPRDA were two years, five years and one year respectively.

72 Agri SA paras 32-46.

73 See similarly Slade 2016 PELJ 4.

74 Emphasis added.

75 See similarly Van Wyk 2016 PELJ 14. PAJA defines administrative action as "any decision taken ... by an organ of state, when exercising a public power or performing a public function in terms of any legislation ... which adversely affects the rights of any person and which has direct, external legal effect". Interestingly, Moseneke DCJ appears to recognise the fact that the expropriation was caused by administrative action towards the end of his judgment: see Van der Walt 2014 ASSL, referring to Arun (CC) para 70.

76 For a different view, see Van der Walt 2014 ASSL, who thinks that Moseneke DCJ categorised the expropriation under $\mathrm{S} 28$ as statutory expropriation. See similarly Van der Sijde Reconsidering the Relationship between Property and Regulation 5-6, 


\subsection{The status of invalid administrative expropriations}

An expropriation that does not comply with one or more of the requirements in section $25(2)$ is invalid. ${ }^{77}$ Such an expropriation may be described as being defective, since it does not comply with all the requirements for it to be valid. This makes it is necessary, in view of the discussion in the previous section, to investigate the status of invalid administrative expropriations.

In Oudekraal Estates (Pty) Ltd $v$ City of Cape Town ${ }^{78}$ (Oudekraal) the Supreme Court of Appeal held that an unlawful or invalid administrative act exists in fact and is capable of producing valid legal consequences for as long as it is not set aside by a court in proceedings for judicial review. ${ }^{79}$ In the Court's view it is unhelpful to use the concepts of "void" and "voidable" when deciding the validity of unlawful administrative acts; the focus should rather fall on whether such acts exist in law or in fact. ${ }^{80}$ The first step of the inquiry therefore entails ascertaining whether an initial administrative act's substantive or legal validity is a necessary

202-203, who describes the vesting of excess land as an ex lege expropriation. Slade 2016 PELJ 18-21, however, questions whether the vesting of excess land in the local authority pursuant to $s 28$ of LUPO amounts to statutory expropriation (or even constructive expropriation). Slade (21-22) also points out that LUPO does not provide a formal expropriation procedure whereby an administrator may expropriate property, which detracts from recognising the vesting of excess land as a formal administrative expropriation. We think his argument is correct in so far as it underscores the invalidity of any "expropriation" which might occur under s 28 of LUPO: see s 3.3 below. For a contrary view, see Van Wyk 2016 PELJ 19-21, who argues that the vesting in the municipality of land indicated as public roads (whether based on the normal need of the development or in excess thereof) results in a $\mathrm{s}$ 25(1) deprivation and not expropriation.

77 Gildenhuys Onteieningsreg 105-109, citing Pharmaceutical Manufacturers paras 5051: "What would have been ultra vires the common law by reason of a functionary exceeding a statutory power is invalid under the Constitution according to the doctrine of legality." See similarly Gildenhuys and Grobler "Expropriation" para 13; Hoexter Administrative Law 255-256.

7820046 SA 222 (SCA).

79 Oudekraal para 26. Also see Judicial Service Commission v Cape Bar Council 2013 1 SA 170 (SCA) para 13; Camps Bay Ratepayers and Residents Association v Harrison 20114 SA 42 (CC) para 62. See similarly Gildenhuys and Grobler "Expropriation" para 26. The same probably holds true for the exercise of public power in the absence of administrative action as well: see Hoexter Administrative Law 254-255.

80 Oudekraal paras 27-30. In view of these findings the distinction made by Gildenhuys Onteieningsreg 107 (citing Wiechers Administratiefreg 179, 336) between void and voidable expropriations no longer has merit. This is probably the reason why Gildenhuys and Grobler "Expropriation" para 26 no longer make this distinction. 
precondition for the validity of subsequent administrative acts. ${ }^{81}$ The same logic applies to the validity of legal consequences that flow from a valid expropriation. In the expropriation context this means that only an expropriation that exists in law is capable of producing valid legal consequences, such as vesting property in the state against payment of compensation under section 25(2). Indeed, the "rule of law dictates that the coercive power of the State [such as expropriation] cannot generally be used against the subject unless the initiating act is legally valid". ${ }^{82}$ It should hence be impermissible for litigants to claim (or for courts to award) compensation for an expropriation that exists only in fact. After all, it is unclear on what basis a party would be able to claim (and for courts to award) expropriatory compensation in the absence of a valid expropriation.

To ascertain the substantive validity of an administrative expropriation, it is necessary to distinguish between two types of defects, namely nonmaterial and material defects. ${ }^{83}$ An example of a non-material defect pertains to the accidental omission of the amount of compensation in the expropriation notice served on the expropriatee. ${ }^{84}$ Defects of this nature are insubstantial and ought not - on their own - to invalidate an administrative expropriation. ${ }^{85}$ In such circumstances a court should be able to condone the deficiency at the insistence of the affected party. In other words, if the defect relates to a non-essential aspect of the requirements for a valid expropriation, the affected party should be afforded an election whether or not to condone the shortcoming against the payment of compensation.

However, the same should not apply to situations where the defect pertains to the essence or substance of an expropriation, in other words to materially defective expropriations. The previous section identifies three grounds that draw the substantive validity of the expropriation in Arun into question - the vesting of excess land in Arun is thus a prime example of

81 Oudekraal paras 31-32. Property holders affected by unlawful administrative acts, even though they are valid until set aside, are entitled to ignore them by raising a defensive or collateral challenge to the validity of the administrative act: see Oudekraal paras 32, 35; and Gildenhuys and Grobler "Expropriation" para 26.

82 Oudekraal para 37.

83 See similarly Gildenhuys Onteieningsreg 85-87.

84 Gildenhuys Onteieningsreg 86, citing Redelinghuys $v$ Stadsraad van Pretoria 19901 SA 555 (T) 558. Gildenhuys (86) also discusses further examples of non-material defects.

85 Gildenhuys Onteieningsreg 87. 
an expropriation that suffers from a number of material defects. ${ }^{86}$ The outcome in this case raises the question whether a materially defective expropriation that therefore exists only in fact and not in law may be treated as a legally valid one that requires the payment of just and equitable compensation, especially since compensation follows on a valid expropriation only. The way in which the Court decided the expropriation question creates the impression that an expropriation will be in order irrespective of its level of defectiveness - as long as it serves some conceivable public interest, against payment of compensation to the affected party. This has major implications for the principles of expropriation law, since an affected property holder may very likely (like Arun) prefer to receive compensation instead of reviewing the (apparent) expropriation under PAJA to have it set aside. In this regard Moseneke DCJ's ruling not only subverts established expropriation principles, as discussed above, ${ }^{87}$ but also contradicts pre-constitutional case law, where defective expropriations comparable to the one in Arun were simply declared invalid and of no effect. ${ }^{88}$ Although the FNB court held that preconstitutional decisions should be treated with circumspection when interpreting the property clause,$^{89}$ this does not mean they should be ignored. The fact that one of the cases, ${ }^{90}$ where the then Appellate Division of the Supreme Court set aside an expropriation aimed at realising a purpose ultra vires the empowering statute, was confirmed by the Constitutional Court ${ }^{91}$ indicates the relevance of (at least some) preconstitutional judgments for adjudicating section 25(2) disputes. ${ }^{92}$

Moseneke DCJ's decision, in as far as it affords litigants a choice between different sources of law that may both be applicable to a set of facts, is

86 See the discussion in s 3.1 above.

87 See the discussion in s 3.1 above.

88 Administrateur, Transvaal v Quid Pro Quo Eiendomsmaatskappy (Edms) Bpk 19774 SA 829 (A) 837-842 (confirmed by the Constitutional Court in Minister of Education $v$ Harris 20014 SA 1297 (CC) paras 17-19); L F Boshoff Investments (Pty) Ltd v Cape Town Municipality; Cape Town Municipality v L F Boshoff Investments (Pty) Ltd 1969 2 SA 256 (C) 268; White River Village Council v H L Hall \& Sons Ltd 19582 SA 524 (A) 530-531; Broadway Mansions (Pty) Ltd v Pretoria City Council 19551 SA 517 (A) 522; Estate Geekie v Union Government 19482 SA 494 (N) 502-503.

$89 \quad$ FNB para 59.

90 Administrateur, Transvaal v Quid Pro Quo Eiendomsmaatskappy (Edms) Bpk 19774 SA $829(\mathrm{~A})$.

91 Minister of Education v Harris 20014 SA 1297 (CC) paras 17-19.

92 Ironically, the pre-constitutional position appears to be nearer to what the spirit, purport and objects of the Bill of Rights requires of the single system of law than the one adopted in Arun (CC): see the discussion of the subsidiarity principles in $\mathrm{s} 4.2$ below. 
furthermore at odds with the single-system-of-law principle. The Arun judgment creates parallel fields of law (expropriation law vis-à-vis administrative law) by permitting litigants to choose between claiming compensation for a materially defective expropriation under section 25(2) or having it reviewed in terms of administrative law (under PAJA, read with section 33) and set aside..$^{93}$ Such an approach disregards the subsidiarity principles developed by the Constitutional Court and may result in outcomes contrary to the spirit, purport and objects of the Bill of Rights. ${ }^{94}$ Litigation under section 25(2) ought in any event - if properly adjudicated - to confirm the outcome of a case based on PAJA, since the property clause (which is part of a single legal system that includes section 33 and PAJA) is unable to produce an outcome where an unlawful administrative act is treated as valid (and requires compensation) if such an outcome would promote administrative injustice through sanctioning unjust administrative action. ${ }^{95}$

Consequently, we argue that courts should not be allowed to uphold materially defective expropriations in the nature of Arun against the payment of compensation, irrespective of whether the expropriation serves a purpose ultra vires the empowering statute or whether the affected property holder might prefer to receive compensation instead of having the expropriation declared invalid and set aside. This is because the expropriation does not exist in law, which makes it impossible for it to generate valid legal consequences such as vesting property in the local authority against payment of compensation. The default remedy for such expropriations should simply be to set the expropriation aside on the basis that it is invalid.

93 We rely on Van der Sijde Reconsidering the Relationship between Property and Regulation 206 to make this argument, who identifies this as one of the possible instances of parallel legal development. She (205-210) identifies the development of different sources of law (ie the Constitution vis-à-vis legislation or the common law) and different constitutional notions (ie meaningful engagement vis-à-vis procedural fairness) as two other instances where parallel legal development may also occur. The subsidiarity principles are discussed in $\mathrm{s} 4.2$ below.

94 See similarly Van der Sijde Reconsidering the Relationship between Property and Regulation 202-203. See further the discussion in $s 4.2$ below.

95 We rely on Van der Walt Property and Constitution 45 to make this argument. Also see Van der Walt's discussion (101 fn 250) of BVerfGE 58, 300 (1981) 324, where he summarises the decision as follows: "it is not constitutionally unjust to expect a person whose rights are affected by administrative action to first attack the action in the administrative courts". Compare Kleyn 1996 SAPL 435 fn 186, 440. See further the discussion of the subsidiarity principles in $\mathrm{s} 4.2$ below. 


\subsection{Conclusion}

In the light of the above, Moseneke DCJ's categorising of the vesting under section 28 as an expropriation that requires compensation is problematic. Instead of setting the materially defective expropriation aside for not complying with the requirements for a valid expropriation, Moseneke DCJ "saved" the provision by awarding compensation to Arun. $\mathrm{He}$ followed this approach despite the fact that the purpose of the expropriation is not sanctioned by section 28 of LUPO. The Court could simply have held that the attempted expropriation is ultra vires the authorising provision and of no effect, thereby obviating the necessity to decide the constitutionality of section $28 .{ }^{96}$ Yet the Court's ruling suggests that non-compliance with one of the substantive requirements for expropriation affords an election to the affected property holder whether to uphold the expropriation so as to receive compensation or to have it set aside. Such a conclusion is erroneous given the role of the public interest requirement in view of the authorisation requirement, the function of compensation in section 25(2), and the distinction between deprivation and expropriation.

Non-compliance with a non-material requirement ought not to render an expropriation invalid per se. However, the same cannot be said of an expropriation that suffers from a material defect. In this context Moseneke DCJ's ruling creates the impression that courts are free to treat materially defective expropriations as legally valid by merely awarding compensation to the affected party. ${ }^{97}$ The fact that the Court decided to uphold the defective expropriation not only creates problems under section 25(2), but also has repercussions for the subsidiarity principles and administrative justice under section 33 of the Constitution and PAJA. For these reasons

96 Marais 2016 SALJ S III(c)(ii).

97 Arun (CC) para 41. Another possibility of explaining Moseneke DCJ's award of compensation to Arun for the vesting of excess land in the local authority might be to view it as a form of what Van der Walt calls "equalisation payments". See Van der Walt Constitutional Property Law 274-282. However, such an explanation is unlikely given the fact that these payments, which must be distinguished from compensation for expropriation, are usually paid for excessive but otherwise lawful deprivations: see Van der Walt Constitutional Property Law 270-282 and Bezuidenhout Compensation ch 4 . Given the fact that $\mathrm{s} 28$ does not authorise a deprivation of land beyond the normal need of the development (Arun CC para 60), it is difficult to see how the compensation Moseneke DCJ awarded to Arun could be some form of equalisation payment. 
the next section considers the role of administrative law when adjudicating expropriation cases. ${ }^{98}$

\title{
4 The relevance of administrative law
}

\subsection{Introduction}

At first glance Arun appears to have little to say about administrative law. In fact, the judgment disposes of its relevance in a single paragraph. ${ }^{99}$ However, a close reading of the facts and the legal problem before the Court strongly suggests that administrative law cannot be summarily discounted. The argument we present here is not that the Court must have applied administrative law, but rather that administrative law should have been considered more seriously. The section also focuses on the Court's reasons for not deciding the case in terms of administrative law principles.

Moseneke DCJ describes the relevance of administrative law as follows: ${ }^{100}$

\begin{abstract}
It is by no means clear that Arun or a developer in its position would be able to seek judicial review of the structure plan only for the reason that it makes provision for higher-order roads which must be provided for in its subdivision application. If the review were to occur under PAJA, as it must, the developer will have to confront a legion of obstacles. It will have to find a decision to impugn. As we have seen vesting occurs ex lege. It will have to seek condonation to overcome the 180-day time bar given that structure plans have long life cycles. It will have to conjure up discrete PAJA review grounds connected to the reasonableness and rationality of the structure plan, its failure to account for a relevant consideration, or a mistake of fact or law and so forth. ${ }^{101}$
\end{abstract}

The scant attention paid to administrative law is not significant in itself. It is significant, though, that the local authority raised the relevance of administrative law and that the Court dismissed it so easily. The Court justifies this ruling on the basis of internal remedies, yet it does not respond to the issue of authorisation for expropriation and compensation, an argument put forward by the city, which has a bearing on the validity of

98 The subsidiarity principles, which are discussed in $s 4.2$ below, underscore the relevance of administrative law when adjudicating s 25(2) cases.

99 Arun (CC) para 66.

100 This paragraph appears in Moseneke DCJ's discussion on the need for the exhaustion of remedies under the heading "[d]id the applicant exhaust its remedies?" However, the question actually addressed by the Court in this part of the judgment is rather "[w]as Arun obliged to make use of an appeal or review process?" (Arun (CC) para 63)

$101 \operatorname{Arun}(\mathrm{CC})$ para 66 (fn omitted). 
the expropriation. ${ }^{102}$ Furthermore, it is significant - if not disconcerting that a coherent methodology for deciding whether or not to apply administrative law is lacking.

Arun provides an interesting case study on the relationship between expropriation law (in terms of section 25(2)) and administrative law. A private party, Arun, is involved in litigation with a local authority exercising its public authority. ${ }^{103}$ Ownership is evaluated in the light of the Constitution, legislation, case law, applications for subdivision and agreements. Thus, a number of private and public considerations and instruments are at play. Ostensibly, the facts suggest that the question of whether or not administrative law should apply would have been entertained in earnest. Given the facts and the broad characterisation of the case, it is unclear why Arun was not decided with reference to PAJA and section 33. Courts are not strictly limited to the arguments proffered by the parties. For instance, in Bato Star Fishing $v$ Minister of Environmental Affairs ${ }^{104}$ (Bato Star) O'Regan $\mathrm{J}$ directed the parties to present their arguments in terms of PAJA. ${ }^{105}$ It is unclear why PAJA was any less relevant in Arun.

Since the Court did not discuss the relevance of administrative law in Arun, this contribution cannot assess the Court's approach directly. However, our investigation focuses on what the Court neglected to consider. We identify a number of considerations that could assist courts in determining whether administrative law should be considered, if not applied, in a given case. In other words, our focus is on what a court should consider for establishing whether administrative law is relevant or not.

\subsection{The internal coherency of the law in view of the subsidiarity principles}

The first consideration concerns the type of protection the law seeks to provide through the Constitution and the Bill of Rights. Should it be possible to obtain very different remedies simply by choosing a remedy based on one fundamental right rather than another? Do the various constitutional rights provide similar, but not identical, protection in relation

\footnotetext{
102 Arun (CC) para 27.

103 Such as the power to expropriate, according to the Court.

10420044 SA 490 (CC).

105 Bato Star paras 21, 26.
} 
to the same set of facts? There is an apparent conflict between the appellant's choice regarding a cause of action and the type of protection the law seeks to provide. For instance, if a litigant were to formulate a complaint on the basis of claiming compensation for an alleged expropriation, rather than the right to administrative justice, would he or she be entitled to very different remedies? If so, is a litigant entitled to exercise this choice absolutely? ${ }^{106}$ The answers to these questions have far-reaching implications. Indeed, it might very well prove to be more lucrative for a litigant to base his or her cause of action on the right to receive compensation for expropriation under section 25(2) rather than to have the expropriation reviewed and set aside under PAJA. Do courts have a say in the applicable legal principles or are they bound to the arguments of the parties? How does a court choose between applying section 25(2) or PAJA, which was enacted to give effect to section 33? ${ }^{107}$ Should it make a difference where both are applicable? If these questions are not taken seriously, courts will not address the phenomenon of litigants cherry picking the cause of action that best suits their own interests, sometimes at the expense of other legally relevant considerations. ${ }^{108}$ The potential of a financially more rewarding remedy under section 25(2) of the Constitution, as opposed to PAJA, seems to have been part of Arun's strategy.

Arun sought protection of its right to receive compensation under section 25(2) for an alleged expropriation. Yet, for reasons discussed earlier, it appears that no valid expropriation had occurred. ${ }^{109}$ The expropriation of excess land is not permitted by the purpose of section 28 of LUPO - it is therefore ultra vires the authorising statute and should be set aside by a court. Yet if a court refuses to entertain the question of authorisation (in terms of either the legality principle under the law-of-general-application requirement in section $25(2)$ or lawfulness under PAJA) a finding of invalidity becomes remote. Where the argument is made that expropriation took place, the legal challenge must address the lawfulness of the decision that results in the expropriation. Normally no compensation would be due for an invalid expropriation, since expropriation is justified by the valid purpose it serves and not the mere payment of compensation. ${ }^{110}$

\footnotetext{
106 Hoexter Administrative Law 255; Van der Walt Property and Constitution 35 et seq.

107 See the discussion of the subsidiarity principles in the paragraphs that follow.

108 See similarly Van der Sijde Reconsidering the Relationship between Property and Regulation 205-206.

109 See the discussion in s 3.1 above.

110 See the discussion in s 3.1 above.
} 
However, this approach to solving the problem is possible only if argument refers to the legality principle or lawfulness under PAJA. On the whole there seems to be a lack of methodology in the Court's approach for deciding cases where two constitutional rights are at play.

In Pharmaceutical Manufacturers Chaskalson P held as follows regarding the nature of the Constitution:

I cannot accept this contention which treats the common law as a body of law separate and distinct from the Constitution. There are not two systems of law, each dealing with the same subject matter, each having similar requirements, each operating in its own field with its own highest court. There is only one system of law. It is shaped by the Constitution which is the supreme law, and all law, including the common law, derives its force from the Constitution and is subject to constitutional control. ${ }^{111}$

A claim of compensation is more likely under some rights, such as section 25(2), whereas the same remedy is more unlikely in terms of other rights, such as under section 33 and PAJA. ${ }^{112}$ Where the Court grants compensation in terms of section 25(2) without giving that right content in relation to administrative justice, in terms of which compensation is unlikely, it seems that the Constitutional Court is subverting the singlesystem-of-law principle by creating parallel fields of law (ie expropriation law vis-à-vis administrative law). ${ }^{113}$ In this regard Moseneke DCJ decided the case before him in terms of expropriation law by awarding Arun compensation under section 25(2) for the alleged expropriation, without reference to the applicability of administrative law. ${ }^{114}$ If all implicated rights in a given set of facts do not inform each other the law is not operating as one system, and that would undermine the rule of law and could have counter-transformative outcomes. ${ }^{115}$

A helpful starting point or methodology for choosing between different sources of law that could apply to a constitutional dispute is presented by the subsidiarity principles developed by the Constitutional Court. ${ }^{116}$ These

111 Pharmaceutical Manufacturers para 44 (emphasis added).

112 Section $8(1)(c)(i)(b b)$ of PAJA provides that the remedy of compensation is possible only in "exceptional cases".

113 See the discussion in the main text surrounding fn 93 above.

114 See the discussion in s 3.3 above.

115 See the discussion in the next few paragraphs below.

116 Van der Walt Property and Constitution 35-39, 91-92. Van der Sijde Reconsidering the Relationship between Property and Regulation 200-201, by drawing on Quinot and Liebenberg 2011 Stell $L R$, describes instances where two constitutional rights (such as ss 25 and 33) are applicable to the same set of facts as "overlap" cases. Given the overlap that exists between expropriation law (s 25(2)) and administrative 
principles derive from the eiusdem-generis principle, which entails that if both a specific law and a general law apply to the same point, parties must frame their arguments in terms of the specific law and may not rely on the general law. ${ }^{117}$ The purpose of these principles is to prevent parties from arbitrarily choosing the source of law that best suits their interests. ${ }^{118}$ This is to ensure, firstly, that in cases of competing legal sources the apparently applicable source demonstrates the desired or positive characteristics that the single-system-of-law principle requires of all law. ${ }^{119}$ The law, ${ }^{120}$ and specifically the applicable source, must promote the spirit, purport and objects of the Bill of Rights and avoid negative features which subvert these values. ${ }^{121}$ Examples of negative features include laws that provide for arbitrary evictions, the weakening of already insecure tenure rights, and administrative injustice. ${ }^{122}$ Positive characteristics would be laws that clearly delineate the purposes for which property may be expropriated by way of administrative action, thus preventing situations where courts award compensation for materially defective administrative expropriations which - in turn - promote administrative injustice. Secondly, the subsidiarity principles avoid counter-transformative outcomes (in the form of the negative features mentioned) by preventing the creation of parallel legal systems. ${ }^{123}$

law (PAJA, read with s 33) in cases where property is expropriated by way of administrative action, it is imperative for courts to follow a methodology for deciding which field of law to apply and to explain this application with reference to the other applicable field. This will ensure that the law operates as a coherent system, thereby realising the positive characteristics envisioned by the single-system-of-law principle: see Van der Sijde Reconsidering the Relationship between Property and Regulation 199-205.

117 Van der Walt Property and Constitution 35-43, citing inter alia Du Plessis Reinterpretation of Statutes 234-236 and Nokotyana $v$ Ekurhuleni Metropolitan Municipality 20104 BCLR 312 (CC) para 50.

118 Van der Walt Property and Constitution 35-39.

119 Van der Walt Property and Constitution 26-27, 40, 95-97.

120 Which consists of various source of law.

121 The same as fn 119 above.

122 Van der Walt Property and Constitution 28-34. See further the discussion in s 3.3 above.

123 Van der Walt Property and Constitution 81-91, 111. Van der Walt (86-87) discusses Tswelopele Non-Profit Organisation $v$ City of Tshwane Metropolitan Municipality 20076 SA 511 (SCA) as an example of where the Supreme Court of Appeal missed an opportunity to develop the common law in accordance with the second subsidiarity principle in that it preferred to craft a new constitutional remedy, which created parallel systems of law. Here the Court specifically created parallel sources of law by crafting a new constitutional remedy (based on the Constitution) without properly explaining why such a remedy is needed with reference to the common-law mandament van spolie. See similarly Van der Sijde Reconsidering the Relationship between Property and Regulation 206. 
The first subsidiarity principle entails that where a litigant claims limitation of a constitutional right, he or she must rely on legislation specifically enacted to protect that right and may not rely directly on the constitutional provision to protect the right. ${ }^{124}$ Litigants are therefore not free to choose the source of law that provides the best remedy; the first subsidiarity principle indicates which legal source should be applied. Yet it must be emphasised that the subsidiarity principles are not rigid rules that create a hierarchy between different constitutional rights - they merely provide a starting point or guidelines for adjudicating cases where two constitutional rights are at stake. ${ }^{125}$

The first principle does not apply to property disputes (such as Arun) directly, since there is no single, comprehensive statute that has been enacted to give content to the whole property clause. ${ }^{126}$ Nevertheless, it applies indirectly to situations where legislation has been enacted to give effect to a non-property constitutional right, such as PAJA, for purposes of section 33. ${ }^{127}$ Although PAJA was enacted to give content to section 33 and not section 25, it has been seen above that most expropriations (and probably the one in Arun as well) occur by way of administrative action. An expropriation that takes place via administrative action must comply with the principles of administrative justice, as set out by section 33 of the Constitution. Since PAJA was enacted to give effect to section 33, it follows that in terms of the first subsidiarity principle litigants will be precluded from basing their cause of action directly on section 25(2) in disputes which concern administrative expropriations - they have to formulate their arguments in terms of PAJA. They will be permitted to rely directly on section 25(2) only if they wish to attack the constitutionality of PAJA for not adequately protecting their rights under section 25(2). ${ }^{128}$

The eiusdem-generis principle and the first subsidiarity principle therefore provide convincing reasons why PAJA should have been considered more seriously in Arun. Indeed, the expropriation under section 28 of LUPO seems to have occurred by way of administrative action, which triggers the

124 Van der Walt Property and Constitution 36-43; Van der Walt 2008 CCR 100-103, citing South African National Defence Union v Minister of Defence 20075 SA 400 (CC) paras 51-52; MEC for Education: KwaZulu-Natal v Pillay 20081 SA 474 (CC) paras 39-40; Chirwa v Transnet Ltd 20082 SA 24 (CC) paras 59 (Skweyiya J), 69 (Ngcobo J).

125 Van der Walt Property and Constitution 14-15, 105, citing Port Elizabeth Municipality $v$ Various Occupiers 20051 SA 217 (CC) para 23.

126 Van der Walt Property and Constitution 42-43.

127 Van der Walt Property and Constitution 43-44.

128 See the sources cited in fn 124 above. 
first subsidiarity principle. Yet Moseneke DCJ preferred to decide the case solely under section 25(2), thereby creating parallel fields of law by arbitrarily awarding compensation for the (materially defective) expropriation under section 25(2) without explaining the reason for this choice with reference to administrative law. In this context the justice misconstrued the public interest and compensation requirements while refusing to apply the relevant legal field (namely PAJA) to establish whether the expropriation was lawful (or accorded with the legality principle in terms of the law-of-general-application requirement under section 25(2)). As mentioned earlier, a proper application of the substantive requirements in section 25(2), namely setting aside the expropriation for being ultra vires section 28 of LUPO, would have had a similar outcome to reviewing the decision that caused the expropriation under PAJA to have it set aside, thereby promoting administrative justice. ${ }^{129}$

The dangers of not adhering to something like the subsidiarity principles are that courts - through arbitrarily choosing the source of law applicable to the case - could deliver judgments that have counter-constitutional and counter-transformative consequences while simultaneously undermining fundamental rights or legislation enacted to give content to those rights, such as PAJA. ${ }^{130}$ Indeed, these dangers seem to have been realised in Arun, where the Constitutional Court not only upheld an expropriation which clearly does not satisfy the section 25(2) requirements but also ignored PAJA, which directly applies to expropriations that occur by way of administrative action. ${ }^{31}$ Affording litigants a choice whether to claim compensation for expropriations that have material defects instead of reviewing them and setting them aside under PAJA (or simply declaring them invalid for being ultra vires the empowering statute) runs contrary to the values which the Bill of Rights seeks to achieve. ${ }^{132}$

In the sections that follow we identify three factors that further strengthen our argument why administrative law should have played a more important role in Moseneke DCJ's judgment. These factors are the nature and

\footnotetext{
129 See similarly Van der Walt Property and Constitution 45.

130 Van der Walt Property and Constitution 26-28, 95-97.

131 In terms of the first subsidiarity principle PAJA also applies directly to deprivations caused by administrative action: see Van der Walt Constitutional Property Law 264270; Van der Sijde Reconsidering the Relationship between Property and Regulation 220-226.

See the main text surrounding fn 122 above.
} 
principles of administrative law, a green-light reading of internal remedies, and deference.

\subsection{The nature of administrative law}

The first consideration is the nature of administrative law. It is relevant because Moseneke DCJ seems to compartmentalise administrative law alongside other legal disciplines or fundamental rights as if it is a set of rules that does not apply in addition to those disciplines and does not inform those disciplines. Administrative law is concerned with "regulating the activities of bodies that exercise public powers or perform public functions". ${ }^{133}$ In this sense, the application of administrative law does not depend on other legal disciplines that happen to be relevant or applicable in a case but rather on the nature of the power or function. Hoexter explains, with reference to Baxter, that "administrative law is ubiquitous: it is a branch of the law that 'permeates virtually every facet of the legal system'. For instance, it applies to public procurement, all forms of licensing, town planning, expropriation". ${ }^{134}$ The examples in the list appear particularly apt in the circumstances of the Arun case. Indeed, one of the issues raised by this judgment is not so much whether administrative law, as opposed to expropriation law, should have been the applicable set of regulatory rules, but rather whether regulation (in the form of expropriation) itself should have been scrutinised. In other words, the Court should have considered how expropriation is regulated. Administrative law is also described as "the regulation of regulation". ${ }^{135}$ Indeed, administrative law is not merely regulatory, it is supra-regulatory. Just as the right to equality is relevant in the application of other human rights disputes, ${ }^{136}$ whether expressly or implicitly, so is the right to just administrative action. The question whether regulation is consistent with the Constitution must take PAJA into consideration.

The Constitutional Court has recognised the interdependence of all rights. ${ }^{137}$ In Government of the Republic of South Africa $v$ Grootboom ${ }^{138}$ it was held that the "Constitution entrenches both civil and political rights and social and economic rights. All the rights in our Bill of Rights are inter-

\footnotetext{
Hoexter Administrative Law 2 (emphasis in original).

Hoexter Administrative Law 10 (fn omitted; emphasis added).

With reference to Farina, see Hoexter Administrative Law 8 (fn omitted).

36 Government of the Republic of South Africa v Grootboom 20011 SA 46 (CC) para 83; Liebenberg Socio-economic Rights 51 et seq.

137 Liebenberg Socio-economic Rights 51 et seq.

13820011 SA 46 (CC).
} 
related and mutually supporting". ${ }^{139}$ The Court also emphasised the importance of the interrelated nature of rights:

[t]he proposition that rights are interrelated and are all equally important is not merely a theoretical postulate. The concept has immense human and practical significance in a society founded on human dignity, equality and freedom. ${ }^{140}$

The interpretation of section 28 of LUPO and section 25(2) of the Constitution was decisive in Arun. However, in this decision the Constitutional Court does not seem to follow the approach the Court itself formulated, namely that all rights must be construed in their context. ${ }^{141}$ The same applies to the non-application of the subsidiarity principles developed by the Court. ${ }^{142}$ What is reasonable in terms of one right will depend on the content of other rights. Is the right to just administrative action not a component of the interpretive context for expropriation? Administrative law is not confined to the application of PAJA; administrative law provides an approach to legal problem solving and the principles of administrative justice inform other rights and the law generally. Thus, reference to administrative law can provide more to legal problem-solving than determining whether there is an administrative action and whether a ground of review succeeds on the facts. We elaborate on this point under the section on green-light theory and deference.

\subsection{Principles of administrative law}

In MEC for Health, Eastern Cape $v$ Kirland Investments (Pty) Ltd t/a Eye \& Lazer Institute ${ }^{143}$ (Kirland) the Constitutional Court recently emphasised the importance of procedural constraints to judicial review in emphatic fashion:

PAJA requires that the government respondents should have applied to set aside the approval, by way of formal counter-application. They must do the same even if PAJA does not apply. To demand this of government is not to stymie it by forcing upon it a senseless formality. It is to insist on due

139 Grootboom para 23.

140 Grootboom para 83. Compare Port Elizabeth Municipality v Various Occupiers 2005 1 SA 217 (CC) paras 8-23, 37.

141 Grootboom para 21: "[i]nterpreting a right in its context requires the consideration of two types of context. On the one hand, rights must be understood in their textual setting. This will require a consideration of Chapter 2 and the Constitution as a whole. On the other hand, rights must also be understood in their social and historical context" (emphasis added). See similarly Port Elizabeth Municipality v Various Occupiers 20051 SA 217 (CC) paras 8-23, 37.

142 See the discussion in 54.2 above.

14320143 SA 481 (CC). 


\begin{abstract}
process[.]
Counsel for the Department told this Court ... that, if the Department had to bring a counter-application under PAJA, it would face the PAJA 180-day rule. Well, precisely ... This Court recently confirmed in Khumalo that litigants, including public functionaries, are bound by statutory and commonlaw time limits and may not circumvent them using procedural tricks. The same is true here. ${ }^{144}$
\end{abstract}

This dictum was written by Cameron $\mathrm{J}$, who delivered the majority judgment in this case. Interestingly, Cameron $\mathrm{J}$ and the three justices ${ }^{145}$ who agreed with him in Kirland endorsed Moseneke DCJ's ruling in Arun. As seen from the quote above, the Kirland court decided that the 180-day rule cannot be circumvented. Nevertheless, in Arun a unanimous Constitutional Court ruled that the expiry of the 180-day period is a factor contributing to its ruling not to review the decision that led to the expropriation of excess land. According to Kirland one cannot avoid relying on PAJA simply because the period for bringing an application for review has expired. However, in Arun the Court seemed to adopt a different approach. It follows that the Arun court avoided administrative law for reasons that are unclear at best and that seem to contradict its decision in Kirland.

Still, the principles of administrative law seem to feature throughout Arun without being named. One notes the reference to internal remedies, which is reminiscent of section 7(2) of PAJA. Moseneke DCJ briefly refers to arbitrariness under section 25(1) of the Constitution, which relates to rationality or reasonableness generally under PAJA. ${ }^{146}$ The Court discusses the purpose for the vesting of land in the local authority in terms of section 28 of LUPO, which can be linked to lawfulness (section $6(2)(a)(I)$ of PAJA) and to reasonableness (section 6(2)( $h)$ of PAJA). Then there is the centrality of the interpretation of section 28 of LUPO to the outcome of the case; its importance relates to the question whether or not the provision authorises expropriation of excess land without compensation. This matter is perhaps the most obvious administrative-law question, namely lawfulness, and yet the court mentions neither lawfulness nor the principle of legality.

\footnotetext{
144 Kirland paras 82-83 (fns omitted; emphasis added).

145 Froneman J, Nkabinde $\mathrm{J}$ and Moseneke ACJ (as he then was).

146 Ss $6(2)(f)(i i)$ and $6(2)(h)$ of PAJA respectively. See similarly Van der Sijde Reconsidering the Relationship Between Property and Regulation 236-243
} 
PAJA is applicable to administrative action only, and therefore the point of departure is determining if there is an administrative action. However, the presence of an administrative action is not decisive - a decision may be unreviewable because of the possibility of internal remedies or because the application was brought too late. ${ }^{147}$ The Court seems to argue that PAJA should not be applied because "the developer will have to confront a legion of obstacles". ${ }^{148}$ The Court's choice of words is dramatic. The legion of obstacles in actual fact consists of only three obstacles, which the Court itself lists. In addition, the obstacles are all required by law. Thus, the legal relevance of characterising these requirements as "obstacles" is questionable. The Court held the appellant would have to "conjure up" discrete PAJA review grounds. The appellant does not have to conjure up grounds of review, since all possible grounds are listed in section 6 of the Act. In any event, why is this relevant? If the law requires a litigant to follow certain steps in order to succeed with an application, then surely that is the end of the matter. ${ }^{149}$ Cameron J's response to such an argument in Kirland, which is quoted above, strengthens this argument.

Moseneke DCJ's wording in the paragraph where he dismisses the need to apply administrative law strongly suggests that the reason why he did not entertain the question "should we apply administrative law?" was because it would have been onerous to the appellant. He also mentions that it is not clear that there is an administrative action on the facts. Whether or not there is an administrative action on the facts is a question the Court should address. If the Court then finds that there is not an administrative action, the reason for not subjecting the decision to judicial review is the absence of an administrative action. In Arun the Court appears to side-step this inquiry on the basis that the presence of an administrative action is uncertain. This is not a justification for avoiding administrative law. Is it in any event ever certain that there is an administrative action before argument on the point is made? Even if one were to assume that there is no administrative action, the state's exercise of public power would always remain subject to the constitutional principle

147 Section 7(2)(a) provides that a court may not review an administrative action unless internal remedies have first been exhausted; $s 7(1)$ of PAJA provides that an application for review "must be instituted without unreasonable delay" and within 180 days.

148 Arun (CC) para 66.

149 See similarly Van der Sijde Reconsidering the Relationship between Property and Regulation 202-203. 
of legality. ${ }^{150}$ At the very least, the legality principle requires proper authorisation when public power is exercised. ${ }^{151}$ Thus, the absence of an administrative action does not excuse the Court from assessing the legality of the purported expropriation.

On the facts, the following decisions could potentially qualify as administrative action: (i) the granting of the subdivision application under section 25 of LUPO, which resulted in the vesting of excess land in the local authority under section 28; (ii) the decision to expropriate; ${ }^{152}$ (iii) the decision not to pay compensation; (iv) the decision that certain portions of land were or were not in excess of the normal need of the planned development; and, finally, the decision that compensation is not the appropriate relief for Arun. The Court in certain parts of the judgment suggests that expropriation is possible without a decision that qualifies as administrative action. ${ }^{153}$ In other words, on the Court's understanding of the facts, excess land is expropriated in the absence of a decision protected by PAJA or the legality principle. Yet the vesting of excess land in the local authority in actual fact seems to have been caused by administrative action, as shown above. ${ }^{154}$

\subsection{Green-light theory and deference}

\subsubsection{Backdrop}

Other factors that could assist in determining whether administrative law should be considered are green-light theory and deference. Green-light theory and deference are discussed below and their relevance to cases such as Arun is set out.

150 Fedsure Life Assurance Ltd $v$ Greater Johannesburg Transitional Metropolitan Council 19991 SA 374 (CC) para 59.

151 Fedsure Life Assurance Ltd $v$ Greater Johannesburg Transitional Metropolitan Council 19991 SA 374 (CC) paras 59, 85; Hoexter Administrative Law 121 et seq. See similarly the discussion of the law-of-general-application requirement in s 25(2), which is discussed in s 3.1 above.

152 The Court assumes that the approval of the rezoning automatically led to the expropriation of excess land, which means the decision to expropriate is linked to the decision to approve the subdivision.

153 See the discussion in s 3.2 above. See similarly Van der Walt 2014 ASSL.

154 See s 3.2 above. See similarly Van der Walt 2014 ASSL. 


\subsubsection{A green-light reading of internal remedies ${ }^{155}$}

Section 7(2)(a) of PAJA provides that no court or tribunal shall review an administrative action in terms of the Act unless any internal remedy provided for in any other law has first been exhausted. Thus, the exhaustion of internal remedies is a precondition for access to judicial review under PAJA. In other words, courts should normally turn away a litigant who has not availed him- or herself of internal remedies. ${ }^{156}$ The use of the word "any" and the fact that there are no qualifiers for the nature of the internal remedy imply that any remedy will suffice, irrespective of whether it is mandatory or voluntary. Where a court is not satisfied that all internal remedies have been exhausted, it must direct the litigant to first exhaust such remedies before instituting proceedings for judicial review under PAJA. ${ }^{157}$ Although this limits the right of access to courts, ${ }^{158}$ it seems to comply with the limitations clause. ${ }^{159}$ Indeed, section 7(2)(c) stipulates that a court may, in exceptional circumstances and on application by an applicant, exempt the applicant from the obligation to exhaust any internal remedy if the interest of justice requires it. ${ }^{160}$ Thus, courts retain a discretionary power to override section $7(2)(a)$. Unfortunately, section 7(2)(a) does not inform the Court's consideration of internal remedies in Arun.

Green-light theory sheds light on the nature of these provisions in PAJA. Harlow and Rawlings ${ }^{161}$ identify two schools of thought regarding the control of state power, namely red-light theory and green-light theory. Redlight theory conceptualises administrative law as a form of control of state power and the judiciary as being responsible for implementing this control. ${ }^{162}$ The rule of law and judicial control are central. Green-light theory regards administrative law as "a vehicle for political progress and welcomes the 'administrative state"'. ${ }^{163}$ Both theories are concerned with

155 In this section an analysis of green-light theory and internal remedies, first canvassed by Maree Investigating an Alternative Administrative-Law System chs 3, 6 , is applied to Arun (CC).

156 Evidently, this provision implicates the right to access to courts. Arguably, access is not denied but delayed.

157 Section $7(2)(b)$ of PAJA.

158 Section 34 of the Constitution.

159 Section 36(1) of the Constitution. See Hoexter Administrative Law 538-543, 593.

160 Section 7(2) (c) of PAJA.

161 Harlow and Rawlings Law and Administration ch 1. Also see Maree Investigating an Alternative Administrative-Law System 66 et seq.

162 Harlow and Rawlings Law and Administration 23; Hoexter Administrative Law 139.

163 Harlow and Rawlings Law and Administration 31. 
the control of state power but where "[r]ed light theory prioritises courts ... green light theory prefers democratic or political forms of accountability". 164 The red-light and green-light theories are distinguished by the source and nature of control.

In terms of green-light theory, courts intervene less and support the executive in the implementation of policy. ${ }^{165}$ Thus, the courts are involved, although their role is dependent on the roles assumed by other state institutions. Green-light theorists prefer internal controls for the administration as opposed to traditional judicial control, which is external. ${ }^{166}$ Internal controls are potentially a more prospective form of control, as opposed to the external and retrospective control of judicial review. ${ }^{167}$ Therefore, green-light theory can be seen as a response to the counter-majoritarian dilemma.

When section 7(2) of PAJA is viewed in terms of the green-light theory, the (potential) nature of the provision comes into focus. Firstly, it provides the authorised decision-maker, typically a member of the executive or administration, an opportunity to rectify its own errors or address the dispute. Secondly, it discourages unnecessary litigation, thereby saving time and financial costs. It also reduces the case load and increases the likelihood of a speedy resolution. Thirdly, it may give a body with specialised expertise in a particular field the opportunity to resolve the dispute. Fourthly, if the internal process allows for an appeal, the protection offered by the administrative tribunal or committee may in fact allow for more protection than the courts can provide under judicial review. Against this backdrop Froneman DJP's (as he then was) authoritative distinction between appeal and review in Carephone (Pty) Ltd v Marcus ${ }^{168}$ should be kept in mind:

[i]n determining whether administrative action is justifiable in terms of the reasons given for it, value judgments will have to be made which will, almost inevitably, involve the consideration of the 'merits' of the matter in some way or another. As long as the Judge determining this issue is aware that he or she enters the merits not in order to substitute his or her own opinion on the

\footnotetext{
164 Harlow and Rawlings Law and Administration 38.

165 Harlow and Rawlings Law and Administration 140.

166 Hoexter Administrative Law 141.

167 Harlow and Rawlings Law and Administration 40; Hoexter Administrative Law $141 \mathrm{fn}$ 184.

16819993 SA 304 (LAC).
} 
correctness thereof, but to determine whether the outcome is rationally justifiable, the process will be in order. ${ }^{169}$

Therefore, in appeal proceedings a tribunal has greater powers than in the review context; an appeal allows the tribunal to consider the merits in order to replace the original decision. This is not possible under review. Thus, in principle, appeal proceedings have the potential to offer greater protection to an aggrieved party. Section 44 of LUPO provides for such an appeal, but since Moseneke DCJ found that expropriation occurred by operation of law, the vesting of land in terms of section 28 of LUPO was not open to appeal.

In addition, section 8 of PAJA provides that a

court, in proceedings for judicial review ... may grant any order that is just and equitable, including orders ...

(c) setting aside the administrative action and ...

(ii) in exceptional cases -

(aa) substituting or varying the administrative action or correcting a defect resulting from the administrative action; or

(bb) directing the administrator or any other party to the proceedings to pay compensation.

Thus, only in exceptional circumstances will a court be able to replace or correct a decision or order the payment of compensation. ${ }^{170}$ In Gauteng Gambling Board $v$ Silverstar Development Ltd ${ }^{171}$ the Supreme Court of Appeal held that "remittal is almost always the prudent and proper course". ${ }^{172}$ Yet compensation is the remedy awarded by the Court in Arun, but on a different basis. The Court could have awarded compensation on the grounds that the case had been pending for a number of years and that it was in the interests of justice to award compensation, rather than under section 25(2) of the Constitution. Nonetheless, Moseneke DCJ awarded compensation to Arun based on section 25(2) and not section $8(c)(i i)(b b)$ of PAJA. However, an internal appeal process can replace the decision as a matter of course. Denying the administration the opportunity to rectify its own mistakes could have the effect of preventing the administration from improving on its decisions, decision-making processes

169 Carephone (Pty) Ltd v Marcus 19993 SA 304 (LAC) para 36.

170 The default remedy is setting aside and remittal: see Hoexter Administrative Law 552; Bleazard and Budlender "Remedies in Judicial Review Proceedings" 251-253.

17120054 SA 67 (SCA).

172 Gauteng Gambling Board v Silverstar Development Ltd 20054 SA 67 (SCA) para 29. 
and dispute resolution. ${ }^{173}$ This is an essential development; after all, the vast majority of disputes or complaints never reach the courts. The transformation of dispute resolution is very much in the hands of the administration.

Fifthly, allowing the authorised decision-maker to rectify its mistake, amend its decision, or to explain itself is inherently democratic, in a majoritarian sense. The section $7(2)(a)$ requirement respects the separation of powers and can also be regarded as a form of deference. The Court asks: "[w]as Arun obliged to make use of an appeal or review process before instituting a claim for compensation?" However, section $7(2)(a)$ suggests that this is not the better question. The question could have been posed differently, namely was there an appeal process that could have shed light on the relevant issues? Green-light theory and deference support such an approach. After all, section 28 of LUPO does not operate in a vacuum, but the Court's decision pivots on the interpretation of the provision in a narrow context (namely section 25(2)) without considering the provisions in PAJA discussed above.

\subsubsection{Dyzenhaus: deference as respect $t^{174}$}

Deference has enjoyed increasing attention since the appearance of Hoexter's seminal article entitled "The Future of Judicial Review in South African Administrative Law". ${ }^{175}$ An exposition of the general theory of deference or of the content of deference as understood by our courts is not provided here, however. It suffices to mention that the Constitutional Court has established deference as a legal principle in South African law and that it remains a prominent topic. ${ }^{176}$

Still, it is necessary to discuss Dyzenhaus's understanding of deference as respect. The reason for this discussion is not merely theoretical, as both Hoexter and O'Regan J draw on Dyzenhaus. Hoexter refers to Dyzenhaus in her article on judicial review, ${ }^{177}$ in which she does not attempt to define deference. She refers to "the sort of deference we should be aspiring

173 This undermines the realisation of administrative justice, which is one of the positive characteristics that the legal system - as a single system of law - should promote: see Van der Walt Property and Constitution 28-34 and the discussion of the subsidiarity principles in $\mathrm{s} 4.2$ above.

174 In this section an analysis of deference, first canvassed in Maree Investigating an Alternative Administrative-Law System chs 3 and 6, is applied to Arun (CC).

175 Hoexter 2000 SALJ.

176 Maree Investigating an Alternative Administrative-Law System 75-98.

177 Hoexter 2000 SALJ. 484-519. Also see Hoexter Administrative Law 151 fn 245. 
to", ${ }^{178}$ adding that "we may perhaps take inspiration from Dyzenhaus's exploration of the idea of deference". ${ }^{179}$ Nevertheless, in Logbro Properties CC $\vee$ Bedderson, ${ }^{180}$ the first case to take judicial notice of Hoexter's notion of deference, deference is defined precisely as Hoexter tentatively described the "sort of deference" she had in mind. O'Regan J, in turn, refers to Dyzenhaus in Bato Star. ${ }^{181}$ Although she relies largely on Hoexter's understanding of deference, she does distinguish between deference as respect and deference as submission. It follows that Dyzenhaus is a source of inspiration in the development of a South African theory of deference.

The reading of Dyzenhaus presented here explores another dimension to deference that has not been adopted by South African courts. Dyzenhaus poses the following questions and his conception of "deference as respect" is his response to them:

[h]ow should judges in common law jurisdictions respond to administrative determinations of the law? Should they defer to such determinations or evaluate them in accordance with their sense of what the right determination should have been?182

Dyzenhaus points out that these questions cannot be answered without considering political and legal theory ${ }^{183}$ and he criticises formalistic arguments that justify judicial review, such as the ultra vires or commonlaw justifications. Dyzenhaus is sceptical of these arguments because they do not acknowledge the legitimate role of the public administration in the state. ${ }^{184}$

Deference as respect introduces a new methodology to judicial decisionmaking by modifying the courts' approach to legal argumentation:

Deference as respect requires not submission but a respectful attention to the reasons offered or which could be offered in support of a decision, whether that decision be the statutory decision of the legislature, a judgment of another court, or the decision of an administrative agency. ${ }^{185}$

\footnotetext{
178 Hoexter 2000 SALJ 501 (emphasis added).

179 Hoexter 2000 SALJ 501 fn 79 (emphasis added). Also see Maree Investigating an Alternative Administrative-Law System 77 et seq.

18020032 SA 460 (SCA).

181 Bato Star para $46 \mathrm{fn} 32$.

182 Dyzenhaus "Politics of Deference" 279.

183 Dyzenhaus "Politics of Deference" 279.

184 De Ville 2006 PELJ 42-43.

185 Dyzenhaus "Politics of Deference" 286.
} 
When a court compartmentalises individual rights, as is seemingly the case in Arun, the "reasons offered or which could be offered" are curtailed. Thus, the right a court chooses to apply changes not only the type of legal argument but also the nature of concepts such as reasonableness and the implications for internal remedies.

The question remains: what does respect entail? The potential effect of deference as respect is far-reaching and fundamental:

\begin{abstract}
[d]eference as respect ... provides an ideal which can inform an attempt to rearticulate the relationships between the legislature, the courts and the administration in such a way that the courts retain a legitimate role as the ultimate authority on the interpretation of law.

In statutory interpretation, this ideal requires of judges that they determine the intention of the statute, not in accordance with the idea that there is some prior (positivistic) fact of the matter, but in terms of the reasons that best justify having that statute. ${ }^{186}$
\end{abstract}

Deference can influence the manner in which the branches of the state interact and the manner in which meaning is given to legal texts. South Africa has adopted a legal system of constitutional supremacy, ${ }^{187}$ founded on human dignity, equality, freedom and democratic principles. The Constitution drives transformation and the administration has a critical role to play in this endeavour. ${ }^{188}$ In such a system the Bill of Rights as a whole, inter alia, must constitute "the reasons that best justify having [a] statute". ${ }^{189}$ Such an approach could have provided a richer template for the interpretation of section 28 of LUPO. ${ }^{190}$ Moseneke DCJ mentions that the relevant legislation must be interpreted in line with section 25(2), yet he fails to say anything about whether it should be read in line with section 33 of the Constitution and PAJA.

Deference as conceptualised by Dyzenhaus involves all the branches of state, not only the judiciary and the administration. Deference requires that judges participate actively in the justification of state action. The courts set out the best reasoning that resulted in a statute and where the interpretation of legislation is contested this process will contribute to

\footnotetext{
186 Dyzenhaus "Politics of Deference" 303.

187 Sections $1(\mathrm{~d}), 2$ of the Constitution.

188 Sections 7, 8, 195, 197(1) of the Constitution.

189 See similarly Van der Walt Property and Constitution 26-27, 95-97.

190 The first subsidiarity principle supports a similar approach for adjudicating disputes where ss 25 and 33 of the Constitution are at play: see the discussion in $\mathrm{s} 4.2$ above.
} 
giving meaning to the legislative provisions. ${ }^{191}$ Thus, where a court can consider an administrative tribunal's reasoning, the "interpretative context" is expanded as a result of this approach. ${ }^{192}$

In other words, courts should treat a tribunal's reasoning with respect, even when the reasoning is not legal, by asking "whether that reasoning did in fact and also could in principle justify the conclusion reached". ${ }^{193} \mathrm{Not}$ applying administrative law, as done by the Court in Arun, decreases the number of relevant arguments and factors which could be taken into consideration, such as the appellant's choice not to make use of internal remedies, the lawfulness of the expropriation or the appropriateness of compensation as a remedy. ${ }^{194}$

The justifications for assuming this "attitude" to judicial decision-making have been developed by a number of authors such as Dyzenhaus, Mullan, and (more recently) Daly. The justifications include the legislature's decision to appoint the tribunal as the primary forum for dispute resolution, the speed and economy with which it can dispose of matters relative to the courts, and its expertise in a particular field. ${ }^{195}$ This approach is not simply derived from the separation of powers. Deference is also justified by democratic principles. ${ }^{196}$

Thus, the core of deference is that courts must take administrative decisions seriously. ${ }^{197}$ However, deference as developed by Dyzenhaus is not how the concept is explained and applied in Bato Star. ${ }^{198}$ Firstly, according to Dyzenhaus, courts should give "independent weight" to the reasoning of administrative decision-makers. ${ }^{199}$ Secondly, the recognition of administrative determinations does not exclude "close judicial scrutiny

\footnotetext{
191 Dyzenhaus "Politics of Deference" 303.

192 Dyzenhaus "Politics of Deference" 303.

193 Dyzenhaus "Politics of Deference" 304 (emphasis added).

194 Compare Marais 2016 SALJ S III(c).

195 Dyzenhaus "Politics of Deference" 303-304. Also see Daly Theory of Deference ch 2 on the central importance of the "declared constitutional principle" of "legislative intent" and ch 3 on the "practical justifications for curial deference", such as expertise and complexity.

196 The "principle" of deference as respect "is inherently democratic. It adopts the assumption that what justifies all public power is the ability of its incumbents to offer adequate reasons for the decisions which affect those subject to them. The difference between mere legal subjects and citizens is the democratic right of the latter to require an accounting for acts of public power." (Dyzenhaus "Politics of Deference" 305.)

197 Dyzenhaus "Politics of Deference" 303.

198 Maree Investigating an Alternative Administrative-Law System 114 et seq.

199 Dyzenhaus "Politics of Deference" 302.
} 
of the tribunal's reasoning". 200 Thirdly, close scrutiny results in the "paradox of rationality"; however, according to Dyzenhaus, close scrutiny and deference are compatible. ${ }^{201}$ Finally, deference as respect changes the "interpretive context", ${ }^{202}$ which has significant implications for judicial decision-making. ${ }^{203}$ Interpreting statutes and administrative determinations of the law thus amounts to a "reconstructive project" and the reasoning may be "legislative, administrative or judicial". 204

Where the administration is concerned, courts must determine whether a decision is "supportable by the reasons it [the administrative tribunal] in fact and could in principle have offered"205 and "even if the reasons in fact given do not seem wholly adequate to support the decision, the court must first seek to supplement them before it seeks to subvert them". ${ }^{206}$ Therefore, where a court assesses the regularity of administrative decisions, that court must perform an additional, constructive function in determining whether the decisions are supportable or justifiable, without compromising close judicial scrutiny. Thus, judges play a proactive role in adjudication.

In Arun a number of public considerations were at stake: the protection of ownership; the obligations associated with maintaining a transport network; the duty to avoid unnecessary or wasteful expenditure (section 195 of the Constitution); the dual nature of administrative law; ${ }^{207}$ the nature of administrative justice; and constitutional and legislative

200 Dyzenhaus "Politics of Deference" 302.

201 Dyzenhaus "Politics of Deference" 302-303. This suggests that deference is not limited to determining the intensity of review (compare Daly Theory of Deference ch 4), nor does close scrutiny of the facts exclude deference as understood by Dyzenhaus.

202 Dyzenhaus "Politics of Deference" 303.

203 Dyzenhaus "Politics of Deference" 303-304. Taking administrative determinations seriously, in the sense advocated by Dyzenhaus, reinforces both the red-light and the green-light theories of administrative law. On the one hand, administrative acts are scrutinised closely and the administration is required to justify its acts. This can be characterised as a form of control. On the other hand, the administration, as the branch specialised in administrative matters, is entitled to justify its actions with reference to the reasons that best justify the decision, even if those reasons are administrative or other reasons.

204 Dyzenhaus "Politics of Deference" 303.

205 Dyzenhaus "Politics of Deference" 305. Dyzenhaus reiterates this point: in the event of recourse to a court "that recourse must be on the basis of the question whether the tribunal's decision was supportable by the reasons it in fact and could in principle have offered". Also see De Ville 2006 PELJ 53 ("Asking whether a decision is justifiable is also different from asking whether a decision is justified.").

206 Dyzenhaus "Politics of Deference" 304 (emphasis added).

207 Maree "Administrative Authorities in Legal Context" 58-59. 
interpretation. Administrative law rules enable the courts to hear arguments on all of these issues and to weigh them against one another. Had Moseneke DCJ asked for the parties to present argument on the judicial review of the decision on the basis of lawfulness or reasonableness he might very well have ordered the appellant to first exhaust its internal remedies under PAJA instead of awarding compensation for the (apparent) expropriation of excess land. This is in line with Dyzenhaus's conception of deference as respect. The judicial act of providing the platform for such argument could be regarded as a form of judicial respect, regardless of the outcome of the case. Deference as respect is not limited to administrative action. If South African courts endorse deference in the form suggested by Dyzenhaus, then the executive's reasoning must not only be taken seriously, courts must seek to supplement the executive's reasoning. One form of supplementing or expanding the "interpretive context" 208 is the opportunity to consider an administrative tribunal's findings.

\section{Conclusion}

This article analyses the Arun judgment from two perspectives, namely expropriation law and administrative law. It highlights the difficulties when courts are faced with cases where more than one fundamental right is implicated - here the right to receive compensation for expropriation under section 25(2) and the right to administrative justice under section 33, read with PAJA. Moseneke DCJ ruled that Arun must be compensated for the expropriation of excess land if section 28 of LUPO is to comply with section 25(2) of the Constitution. Unfortunately, this outcome is problematic in terms of both section 25(2) and PAJA.

The decision is unattractive from a section 25(2) perspective for four reasons. Firstly, it misconstrues the role of the public interest requirement for expropriation when understood in terms of the law-of-generalapplication requirement, as informed by the legality principle. The state may expropriate property only for purposes permitted by an authorising statute. Yet Moseneke DCJ acknowledged that section 28 of LUPO does not permit the expropriation of excess land for the purpose of aiding the construction of higher-order roads. It follows that the attempted expropriation is ultra vires the empowering legislation and should thus have been set aside, since the state cannot use the power to expropriate 
property for purposes other than those permitted by the empowering legislation. However, the Court preferred to "save" section 28 by awarding compensation to Arun. This finding, in turn, disregards the function of compensation in expropriation law, namely that it is merely a consequence of a valid expropriation and not a justification for it. Thirdly, the Arun court placed too much emphasis on the effect of the property limitation to decide the expropriation question. This approach is erroneous because it oversimplifies the distinction between deprivation and expropriation. Finally, awarding compensation for the invalid expropriation under section 28 seems to afford litigants an election whether to uphold a materially defective administrative expropriation against payment of compensation or to have it reviewed under PAJA to have it set aside. Such an approach holds negative repercussions for the single-system-of-law principle because it creates parallel fields of law, which has the potential of undermining the spirit, purport and objects of the Bill of Rights.

From an administrative law perspective we identify four considerations that indicate why PAJA should have played a more prominent role in Moseneke DCJ's judgment. The first is the internal coherency of the law in view of the subsidiarity principles. In Pharmaceutical Manufacturers it was held that we have a single system of law - all law derives its force from the Constitution. Against this background the Constitutional Court developed a number of subsidiarity principles that provide a methodology when ascertaining which source of law should be applied to a dispute in cases where more than one fundamental right is applicable. The rationale behind these principles is to ensure that the law exhibits the positive characteristics which support the spirit, purport and objects of the Bill of Rights, such as ensuring that administrative expropriations take place only for purposes authorised by the empowering statute, which promotes administrative justice. The fact that Moseneke DCJ preferred to uphold an invalid expropriation by awarding compensation amounts to condoning an unlawful administrative act aimed at realising a purpose which is not sanctioned by the empowering legislation. This, in turn, runs contrary to both section 25(2) and the right to just administrative action under section 33.

Secondly, the Constitutional Court's refusal to follow PAJA in Arun by reason of it being onerous on the appellant contradicts its earlier case law, where it held that time-periods under the Act cannot be circumvented by reason of them being burdensome. The rationale behind these timeperiods is integral to securing administrative justice, since time-periods are 
not merely formalistic technicalities. Time periods prevent unnecessary delays and enable courts to hear matters before too much time has passed, ${ }^{209}$ which (in turn) promotes legal certainty. In addition, section 7(1) of PAJA contains a rule against unreasonable delay, in addition to the 180-day rule.

Thirdly, we argue that a green-light approach to internal remedies could have resulted in the broadening of the interpretative context and the recognition of the legitimate role of the public administration in the state. The Court's approach in finding that excess land vests in the local authority ex lege does not take into consideration the significance of internal remedies and its approach leads to the finding that section 44 of LUPO does not provide for an internal appeal of decisions flowing from section 28 of the Ordinance. By failing to seriously consider the legitimate role of the administration in the state and the administration's interpretation of law, internal and more democratic forms of control are undermined. ${ }^{210}$ As stated above, the Court considers whether the internal appeal or review process is mandatory. However, green-light theory and section 7(2)(a) of PAJA suggest that the role that internal appeals could play should form part of the Court's interpretive approach, rather than merely focussing on the provisions of LUPO in isolation. In other words, the legitimate role of the administration and the role of internal processes should be assessed in the light of South Africa's human rights culture ${ }^{211}$ and not in a vacuum.

Finally, deference as understood by Dyzenhaus also exemplifies why administrative law should not be ignored in cases which concern the exercise of public power. Administrative law regulates the relationship between the executive and the administration, of which deference is a definitive component in the South African context. ${ }^{212}$ The core of deference as understood by Dyzenhaus is that courts must take administrative decisions and determinations of the law seriously. ${ }^{213}$ One way of achieving this is by affording the administration an opportunity to rectify its errors. If the matter remains unresolved, courts will have the benefit of being able to consider the administrative decision-maker's reasons. In Arun the Court neither affords the administration this

\footnotetext{
209 This facilitates access to evidence and the reliability of oral testimony.

210 Hoexter Administrative Law 141.

211 Davis 2006 Acta Juridica 23-41.

212 Maree Investigating an Alternative Administrative-Law System.

213 Dyzenhaus "Politics of Deference" 303.
} 
opportunity nor regards the appellant's failure to make use of internal procedures as problematic.

Deference also requires courts to actively participate in the justification of administrative decisions by asking whether the administration's "reasoning did in fact and also could in principle justify the conclusion reached". ${ }^{214}$ As with green-light theory, deference as respect changes the "interpretive context". ${ }^{215}$ Such an approach to the scrutiny of administrative decisions is far-reaching: "even if the reasons in fact given do not seem wholly adequate to support the decision, the court must first seek to supplement them before it seeks to subvert them". ${ }^{216}$ This approach does not threaten a court's role, because deference as respect does not exclude "close judicial scrutiny of the tribunal's reasoning". ${ }^{217}$ In Arun, however, the Constitutional Court construes section 28 of LUPO by means of a narrow, textual approach to interpretation. ${ }^{218}$ By choosing not to engage with the implications of administrative justice, the court side-steps critical constitutional debates on the separation of powers, on constitutional supremacy and the single-system-of-law principle, and on the relationship between the administration and judiciary in a democratic state as well as administrative law and expropriation law. Ironically, Moseneke DCJ introduces his judgment with the following sentence: "[t]his appeal raises a significant constitutional issue connected to the expropriation of land and compensation". ${ }^{219}$ Regrettably, he does not seem to appreciate the significance of the constitutional issue, opting instead to resolve the question solely on the basis of section 25(2).

It remains to be seen how Moseneke DCJ's judgment will impact future planning law disputes similar to Arun. The Spatial Planning and Land Use Management Act 16 of 2013 (SPLUMA), which came into effect on 1 July 2015, applies nationally, and although it does not directly repeal planning laws like LUPO, it stipulates that

no legislation not repealed by this Act [such as LUPO] may prescribe an alternative or parallel mechanism, measure, institution or system on spatial planning, land use, land use management and land development in a manner inconsistent with the provisions of this Act.

\footnotetext{
214 Dyzenhaus "Politics of Deference" 304 (emphasis added).

215 Dyzenhaus "Politics of Deference" 303.

216 Dyzenhaus "Politics of Deference" 304 (emphasis added).

217 Dyzenhaus "Politics of Deference" 302.

218 See similarly Marais 2016 SALJ s III(c).

$219 \operatorname{Arun}(\mathrm{CC})$ para 1.
} 
SPLUMA does not contain a provision similar to section 28 of LUPO, 220 which means it is therefore unlikely that a case such as Arun would be brought under this Act. 221 Yet section 37(2) of the Western Cape Land Use Planning Act 3 of 2014 (LUPA) ${ }^{222}$ provides that

[a] municipality is not liable for compensation for the land [earmarked for a public place] if the provision of the public place is based on the normal need therefor arising from the subdivision.

This provision is strikingly similar to section 28 of LUPO, especially since the definition of "public place" in LUPA includes streets and roads. ${ }^{223}$ It will therefore be interesting to see whether the Constitutional Court will apply its (flawed) approach towards section 28 to disputes under section 37(2) of LUPA and whether it will perhaps reconsider its ruling in view of the criticism raised in this contribution as well as by various other authors. ${ }^{224}$ Until clarity is obtained, Western Cape municipalities had best be prudent when they indicate the amount of land required for public roads when approving development plans under LUPA, as a developer will be entitled to receive compensation (in terms of section 26(1) of the Expropriation Act) for any land that vests in the local authority and which is in excess of the normal need of the proposed development.

\section{Bibliography}

\section{Literature}

Badenhorst, Pienaar and Mostert Silberberg and Schoeman

Badenhorst PJ, Pienaar JM and Mostert H Silberberg and Schoeman's The Law of Property $5^{\text {th }}$ ed (LexisNexis Durban 2006)

Bezuidenhout Compensation

Bezuidenhout K Compensation for Excessive but Otherwise Lawful Regulatory State Action (LLD-thesis University of Stellenbosch 2015)

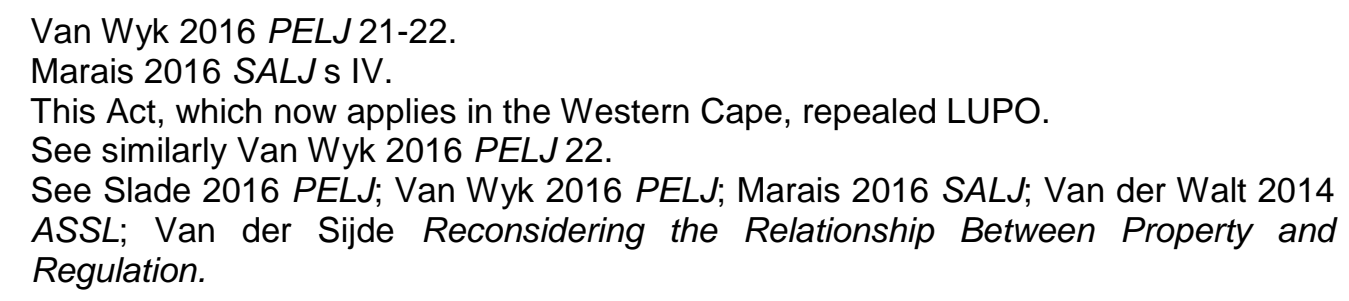


Bleazard and Budlender "Remedies in Judicial Review Proceedings" Bleazard $\mathrm{J}$ and Budlender S "Remedies in Judicial Review Proceedings" in Quinot G (ed) Administrative Justice in South Africa: An Introduction (Oxford University Press Oxford 2015) 237-278

Daly Theory of Deference

Daly P A Theory of Deference in Administrative Law: Basis, Application and Scope (Cambridge University Press Cambridge 2012)

Davis 2006 Acta Juridica

Davis DM "To Defer and Then When? Administrative Law and Constitutional Democracy" 2006 Acta Juridica 23-41

De Ville 2006 PELJ

De Ville JR "Judicial Deference and Différance: Judicial Review and the Perfect Gift" 2006 9(2) PELJ 41-89

Du Plessis Re-interpretation of Statutes

Du Plessis LM Re-interpretation of Statutes (LexisNexis Butterworths Durban 2002)

Dyzenhaus "Politics of Deference"

Dyzenhaus D "The Politics of Deference: Judicial Review and Democracy" in Taggart M (ed) The Province of Administrativ Law (Hart Oxford 1997) 279-307

Gildenhuys Onteieningsreg

Gildenhuys A Onteieningsreg $2^{\text {nd }}$ ed (Butterworths Durban 2001)

Gildenhuys and Grobler "Expropriation"

Gildenhuys A and Grobler GL "Expropriation" in Kanjan A (ed) Law of South Africa (LexisNexis Durban 2012) Paras 1-156

Harlow and Rawlings Law and Administration

Harlow C and Rawlings R Law and Administration $3^{\text {rd }}$ ed (Cambridge University Press Cambridge 2009)

Hoexter 2000 SALJ

Hoexter $C$ "The Future of Judicial Review in South African Administrative Law" 2000 SALJ 484-519 
Hoexter Administrative Law

Hoexter C Administrative Law in South Africa $2^{\text {nd }}$ ed (Juta Claremont 2012)

\section{Hoops 2016 SALJ}

Hoops B "Specificity of Expropriation Statutes as a Safeguard against Third Party Transfers for Economic Development: Lessons from German Law for New Expropriation Legislation in South Africa?" (2016 forthcoming) SALJ

Kleyn 1996 SAPL

Kleyn DG "The Constitutional Protection of Property: A Comparison between the German and the South African Approach" 1996 SAPL 402445

Liebenberg Socio-economic Rights

Liebenberg S Socio-economic Rights: Adjudication under a Transformative Constitution (Juta Cape Town 2010)

Marais 2015 PELJ (Part I)

Marais EJ "When Does State Interference with Property (Now) Amount to Expropriation? An Analysis of the Agri SA Court's State Acquisition Requirement (Part I)" 2015 PELJ 2983-3031

Marais 2015 PELJ (Part II)

Marais EJ "When Does State Interference with Property (Now) Amount to Expropriation? An Analysis of the Agri SA Court's State Acquisition Requirement (Part II)" 2015 PELJ 3033-3069

Marais 2016 SALJ

Marais EJ "A Common-Law Presumption, Statutory Interpretation and Section 25(2) of the Constitution - A Tale of Three Fallacies. A Critical Analysis of the Constitutional Court's Arun Judgment" (2016 forthcoming) SALJ

Maree Investigating an Alternative Administrative-Law System

Maree PJH Investigating an Alternative Administrative-Law System in South Africa (LLD-thesis University of Stellenbosch 2013) 
Maree "Administrative Authorities in Legal Context"

Maree PJH "Administrative Authorities in Legal Context" in Quinot G (ed) Administrative Justice in South Africa: An Introduction (Oxford University Press Oxford 2015) 27-64

Quinot and Liebenberg 2011 Stell LR

Quinot $G$ and Liebenberg $S$ "Narrowing the Band: Reasonableness Review in Administrative Justice and Socioeconomic Rights Jurisprudence in South Africa" 2011 Stell LR 639-663

Roux "Property"

Roux T "Property" in Woolman S, Roux T and Bishop M (eds) Constitutional Law of South Africa $2^{\text {nd }}$ ed (Juta Cape Town 2003) 46-1 46-37

Slade 2013 TSAR

Slade BV "The Less Invasive Means Argument in Expropriation Law" 2013 TSAR 199-216

Slade 2016 PELJ

Slade BV "Compensation for What? An Analysis of the Outcome in Arun Property Development (Pty) Ltd v Cape Town City" 2016 PELJ 1-25

Steyn Uitleg van Wette

Steyn LC Die Uitleg van Wette $5^{\text {th }}$ ed (Juta Cape Town 1981)

Van der Merwe Sakereg

Van der Merwe CG Sakereg $2^{\text {nd }}$ ed (Butterworths Durban 1989)

Van der Sijde Reconsidering the Relationship between Property and Regulation

Van der Sijde E Reconsidering the Relationship between Property and Regulation: A Systemic Constitutional Approach (LLD-thesis University of Stellenbosch 2015)

Van der Walt Constitutional Property Clauses

Van der Walt AJ Constitutional Property Clauses: A Comparative Analysis (Juta Cape Town 1999)

Van der Walt 2008 ASSL

Van der Walt AJ "Constitutional Property Law" 2008 ASSL 231-264 
Van der Walt 2008 CCR

Van der Walt AJ "Normative Pluralism and Anarchy: Reflections on the 2007 Term" 2008 CCR 77-128

Van der Walt Constitutional Property Law

Van der Walt AJ Constitutional Property Law $3^{\text {rd }}$ ed (Juta Cape Town 2011)

Van der Walt Property and Constitution

Van der Walt AJ Property and Constitution (PULP Pretoria 2012)

Van der Walt 2014 ASSL

Van der Walt AJ "Constitutional Property Law" (2014 forthcoming) ASSL

Van der Walt and Botha 1998 SAPL

Van der Walt AJ and Botha $\mathrm{H}$ "Coming to Grips with the New Constitutional Order: Critical Comments on Harksen v Lane NO" 1998 SAPL $17-41$

Van der Walt and Marais 2012 LitNet Akademies

Van der Walt AJ and Marais EJ "Eiendomsverlies Weens Verkrygende Verjaring: 'n Ongekompenseerde Onteiening - Of Nie?" 2012 LitNet Akademies 298-321

Van Wyk Planning Law

Van Wyk J Planning Law $2^{\text {nd }}$ ed (Juta Cape Town 2012)

Van Wyk 2016 PELJ

Van Wyk J "Planning and Arun's (Not So Straight and Narrow) Roads" 2016 PELJ $1-29$

Wiechers Administratiefreg

Wiechers M Administratiefreg $2^{\text {nd }}$ ed (Butterworths Durban 1984)

Woolman and Botha "Limitations"

Woolman S and Botha H "Limitations" in Woolman S, Roux T and Bishop M (eds) Constitutional Law of South Africa $2^{\text {nd }}$ ed (Juta Cape Town 2006) ch 34 


\section{Case law}

\section{South Africa}

Administrator, Cape v Associated Buildings Ltd 19572 SA 317 (A)

Administrator, Cape Province v Ruyteplaats Estates (Pty), Ltd 19521 SA $541(\mathrm{~A})$

Administrateur, Transvaal v Quid Pro Quo Eiendomsmaatskappy (Edms) Bpk 19774 SA 829 (A)

Agri South Africa v Minister for Minerals and Energy 20134 SA 1 (CC)

Arun Property Development (Pty) Ltd v Cape Town City 20152 SA 584 (CC)

Bato Star Fishing (Pty) Ltd v Minister of Environmental Affairs 20044 SA 490 (CC)

Beckenstrater v Sand River Irrigation Board 19644 SA 510 (T)

Belinco (Pty) Ltd v Bellville Municipality 19704 SA 589 (A)

Broadway Mansions (Pty) Ltd v Pretoria City Council 19551 SA 517 (A)

Camps Bay Ratepayers and Residents Association v Harrison 20114 SA 42 (CC)

Carephone (Pty) Ltd v Marcus 19993 SA 304 (LAC)

Chirwa v Transnet Ltd 20082 SA 24 (CC)

City of Cape Town v Arun Property Developments (Pty) Ltd 2014 JDR 0786 (SCA)

City of Cape Town v Helderberg Park Development (Pty) Ltd 20086 SA 12 (SCA)

Club Mykonos Langebaan Ltd $v$ Langebaan Country Estate Joint Venture 20093 SA 546 (C)

Estate Geekie v Union Government 19482 SA 494 (N) 
Fedsure Life Assurance Ltd $v$ Greater Johannesburg Transitional Metropolitan Council 19991 SA 374 (CC)

Fernwood Estates Ltd v Cape Town Municipal Council 1933 CPD 399

First National Bank of SA Ltd t/a Wesbank v Commissioner, South African Revenue Service; First National Bank of SA Ltd t/a Wesbank v Minister of Finance 20024 SA 768 (CC)

Gauteng Gambling Board v Silverstar Development Ltd 20054 SA 67 (SCA)

Government of the Republic of South Africa v Grootboom 20011 SA 46 (CC)

Groengras Eiendomme (Pyt) Ltd $v$ Elandsfontein Unlawful Occupants 20021 SA 125 (T)

Harksen $v$ Lane 19981 SA 300 (CC)

Harvey v Umhlatuze Municipality 2011 1 SA 601 (KZP)

Joyce \& McGregor Ltd v Cape Provincial Administration 1946 AD 658

Judicial Service Commission v Cape Bar Council 20131 SA 170 (SCA)

L F Boshoff Investments (Pty) Ltd v Cape Town Municipality; Cape Town Municipality v L F Boshoff Investments (Pty) Ltd 19692 SA 256 (C)

Logbro Properties CC v Bedderson 20032 SA 460 (SCA)

MEC for Education: KwaZulu-Natal v Pillay 20081 SA 474 (CC)

MEC for Health, Eastern Cape $v$ Kirland Investments (Pty) Ltd t/a Eye \& Lazer Institute 20143 SA 481 (CC)

Minister of Education v Harris 20014 SA 1297 (CC)

Minister of Health v New Clicks South Africa (Pty) Ltd 20062 SA 311 (CC)

Minister of Minerals and Energy v Agri South Africa 20125 SA 1 (SCA)

Nokotyana v Ekurhuleni Metropolitan Municipality 20104 BCLR 312 (CC)

Oudekraal Estates (Pty) Ltd v City of Cape Town 20046 SA 222 (SCA) 
Pharmaceutical Manufacturers Association of South Africa: In re Ex Parte President of the Republic of South Africa 20002 SA 674 (CC)

Port Elizabeth Municipality v Various Occupiers 20051 SA 217 (CC)

President of the Republic of South Africa v Modderklip Boerdery (Pty) Ltd 20055 SA 3 (CC)

Pretoria City Council v Modimola 19663 SA 250 (A)

Redelinghuys v Stadsraad van Pretoria 19901 SA 555 (T)

Reflect-All 1025 CC v MEC for Public Transport, Roads and Works, Gauteng Provincial Government 20096 SA 391 (CC)

South African National Defence Union v Minister of Defence 20075 SA 400 (CC)

South Peninsula Municipality v Malherbe 19992 SA 966 (C)

Tongaat Group Ltd v Minister of Agriculture 19772 SA 961 (A)

Tswelopele Non-Profit Organisation v City of Tshwane Metropolitan Municipality 20076 SA 511 (SCA)

Van Eck and Van Rensburg v Etna Stores 19472 SA 984 (A)

White River Village Council v H L Hall \& Sons Ltd 19582 SA 524 (A)

\section{Germany}

BVerfGE 58, 300 (1981)

\section{United States}

Dolan v City of Tigard 512 US 374 (1994)

\section{Legislation}

Constitution of the Republic of South Africa, 1996

Expropriation Act 63 of 1975

Expropriation Bill B4D-2015 
Land Reform (Labour Tenants) Act 3 of 1996

Land Use Planning Ordinance 15 of 1985 (C)

Mineral and Petroleum Resources Development Act 28 of 2002

Promotion of Administrative Justice Act 3 of 2000

Spatial Planning and Land Use Management Act 16 of 2013

Township Ordinance 33 of 1934 (C)

Western Cape Land Use Planning Act 3 of 2014

\section{List of Abbreviations}

ASSL

CCR

LUPA

LUPO

MPRDA

PAJA

PELJ

SALJ

SAPL

SPLUMA

Stell LR

TSAR
Annual Survey of South African Law

Constitutional Court Review

Western Cape Land Use Planning Act

Land Use Planning Ordinance

Mineral and Petroleum Resources

Development Act

Promotion of Administrative Justice Act

Potchefstroom Electronic Law Journal

South African Law Journal

South African Public Law

Spatial Planning and Land Use Management Act

Stellenbosch Law Review

Tydskrif vir die Suid-Afrikaanse Reg 